\title{
Fotojenik Makyajdan Plastik Makyaja 2000'li Yıllar Öncesi Türk Sinemasında Makyaja Genel Bir Bakış
}

\author{
Ferhat Zengin (Dr. Öğr. Üyesi) \\ İstanbul Gelişim Üniversitesi Uygulamalı Bilimler Yüksekokulu \\ ferhatbzengin@gmail.com \\ ORCID: 0000-0002-6785-3257
}

Başvuru Tarihi: 05.08.2019

Yayına Kabul Tarihi: 28.12.2019

Yayınlanma Tarihi: 24.01.2020

DOI: http://10.17680/erciyesiletisim.601909

\section{Öz}

Sinemanın görsel etkisini artıran öğelerden biri makyajdır. Makyaj sahne atmosferinin ve sinemasal gerçeklik hissinin oluşmasında önemli bir anlatım aracıdır ve özellikle karakter ve tip yaratımında oyuncuların sergiledikleri kişilikleri yansıtmak için ihtiyaç duyulur. Dolayısıyla hareketli görüntülerin doğuşundan itibaren film endüstrilerinde makyaj bir meslek olarak kabul edilmiş, makyaj sanatçllarının uygulamaları önemsenmiş ve ödüllendirilmiştir. Sektörleşme adına büyük sıkıntılar yaşayan Türk sinemasında ise yıllarca görmezden gelinen makyaj, bir meslek olarak uzun yıllar var olmaya çalışmıştır. $\mathrm{Bu}$ çalışmada makyaj sanatının Türk sinemasındaki tarihsel gelişim ve dönüşümü ele alınmış, 2000 öncesi Türk sinemasında makyaj sanatının yerli film sektöründeki konumu araştırılmıştır. Çalışmada derinlemesine görüşme gerçekleştirilmiş, literatür ve arşiv taraması yapılmış, çeşitli makyaj uygulamaları amaca yönelik örnek yerli filmler üzerinden gösterilmeye çalışılmıştır. Böylelikle elde edilen bilgiler ışığında 2000'li yıllar öncesi Türk sinemasında makyajın durumu ortaya konulmuştur. Çalışmaya göre, Türk sinemasında tiyatro geleneğinin bir devamı olarak ilk öykülü filmlere geçtikten sonra yönetmenlerin, oyuncuların ya da setteki kişiler tarafından amatör ve bilinçsizce yapılan daha çok "güzel görünüş" amaçlı makyaj uygulamaları, daha sonra makyaja ilgi duyan sınırlı sayıdaki kişiler tarafından kişisel gayretler ve deneyimlerle sürdürülmüștür. Türk sinemasında karakter ve tip yaratımında plastik makyaj uygulamaları da yapabilen alanında uzman, profesyonel sanatçıların yetişmesi ise televizyonun gelişiyle olmuştur.

Anahtar Kelimeler: Türk Sineması, Makyaj, Kozmetik Makyaj, Plastik Makyaj. 


\title{
From Photogenic Make-Up to Plastic Make-Up: Overview of Make-Up in Turkish Cinema before 2000s
}

\author{
Ferhat Zengin (Asst. Prof. Dr.) \\ İstanbul Gelişim University School of Applied Sciences \\ ferhatbzengin@gmail.com \\ ORCID: 0000-0002-6785-3257
}

Date Received: 05.08.2019

Date Accepted: 28.12.2019

Date Published: 24.01.2020

DOI: http://10.17680/erciyesiletisim.601909

\begin{abstract}
One of the elements that increase visual effect of cinema is make-up. Make-up is the most important narrative tool to create stage atmosphere and cinematic reality feeling and make-up is especially needed to reflect personalities staged by actors in character and type creation. Therefore, from the birth of motion images, make-up has been accepted as an occupation in film industry, applications of make-up artists have been cared and rewarded. In Turkish cinema that experienced significant issues in terms of becoming a sector has been overlooked for years and struggled to exist as an occupation for long years. In this study, historical development and transformation of make-up art in Turkish cinema is considered and position of make-up art in pre-2000s Turkish local cinema is investigated. This study applied in-depth interviews, literature and archive review and various make-up applications are presented with purpose-oriented local movies. Thus, based on obtained data, states of make-up in Turkish cinema before 2000s has been reflected. According to this study, after transition to first story films as a continuation of theatre tradition, make-up applications for "beautiful look" applied unconsciously by directors, actors or set personnel in Turkish cinema is later sustained by personal efforts and experience of limited number of individuals interested in make-up. Raising expert and professional artists who can apply plastic make-up for character and type creation in Turkish cinema started with television.
\end{abstract}

Keywords: Turkish Cinema, Make-up, Cosmetic Make-up, Plastic Make-up. 


\section{Giriş}

Sinemanın görsel ve işitsel duyulara etkileşimi açık olan kendine özgü anlatım araçlarına sahip olması onu diğer sanatlardan farklı kılmaktadır. Anlatısıyla (öykü/ hikâye), sinematografisiyle, mizanseniyle, kurgu yapısı ve ses düzeniyle söz konusu bu temel öğeler, bir kombinasyon ve estetik içinde film dilini ve anlamını dolayısıyla eserin kendisini oluşturmaktadır. Eserin kendisinin var olmasında öncü rolü oynayan yönetmen de hayalindeki film evrenini söz konusu dramatik yapıları kullanarak inşa eder ve bunu seyirciye görsel bir şölenle aktarır. Seyirci de kendisine sunulan bu görsel şölen içinde kendi düş gücü çerçevesinde yönetmenin dünyasıyla iletişime geçer ve çeşitli göstergelerle anlama ulaşmaya çalışır. Bu bağlamda yönetmen sinemanın anlatı araçlarını dramatik anlatıya uygun bir kompozisyonla bağlaması gerekmektedir. Çünkü "iyi bir kompozisyon, görsel malzemenin uyumlu bir bütün oluşturacak biçimde düzenlemesidir" (Mascelli, 2007, s. 207). İyi bir kompozisyon da mizansenin başarılı bir şekilde oluşturulmasıyla mümkündür. Sinemanın "fotoğrafik imge, çerçeveleme, hareket, kurgu ve ses" (David Bordwell, 2012, s. 162) gibi anlatım araçlarından biri olan mizansen, "görüntü çerçevesi içinde yer alan unsurların düzenlenmesi almanına gelir" (Ryan \& Lenos, 2014, s. 17) Fransızcadan "mise-en-scène" sözcügünden türetilen Türkçede "sahneye koyma" anlamına gelen mizansen kelimesi tiyatro ve sinemada "yönetmenin belli bir oyun içinde oyuncuları düzene alması ve onları oyuna uygun bir uyum içine sokması için yaptığı hazırlık, çalışma" (TDK) olarak açıklanır. Mizansen, "sahnelenen eylemle doğrudan ilişkisi bulunan mizansenin, temel olarak altı öğesi vardır. Dekor/mekân, aydınlatma, kostümler, saç, makyaj ve karakterlerin hareketleri mizansenin öğeleridir (Villarejo, 2007:156). Günümüzde mizansen daha geniş anlamda kullanılmaktadır. Mizansen, yönetmen ya da yapımcının, izleyicinin alımlamasını yönlendirmek ve şekillendirmek üzere perde için oluşturduğu; set kurulumundan kostüm tasarımına, aktörlerin performansından aydınlatmaya ve kamera açıları, kamera hareketleri, kameranın uzaklığı, sesin kullanımı ve kompozisyon oluşturmaya kadar tüm film tekniklerini kapsayan çekimle ilgili her şeyi içerir" (Kabadayı, 2014, s. 45). Mizanseni oluşturan her bir öğe filmin gerçekçiliğini ortaya koyan belirleyici unsurlardır ve bu öğeler birbiri ile ilișik olarak düzenlenir. Dolayısıyla mizanseni oluşturan her bir öğe önemlidir. Bu önemli öğelerden biri de makyajdır.

Uygulama pratikleri insanlık tarihine kadar uzanan makyaj, Fransızca kökenli bir kelime olup "yüzü güzelleștirmek için boyama, yüz boyama, yüz bakımı" (TDK) olarak tanımlanmaktadır. Bireysel değişim ve dönüşüm aracı olarak kişinin kendi yüzüne veya bedeninin herhangi bir yerine uyguladığı "güzel görünüm" amaçlı söz konusu bu pratikler kişinin ait olduğu dönemin, zamanın ve yaşam biçiminin göstergeleridir. Bu bağlamda makyaj sadece güzellik aracının bir nesnesi değil aynı zamanda tarihsel, toplumsal, kültürel ve inanç kodlarını da beraberinde taşıyan bir olgudur. Söz konusu bu olgu farklı sanat dallarında eser yaratımının vazgeçilmez bir unsuru olarak kullanılmaktadır. "İyi görüntü sağlamak, belli bir tip yaratmak veya yalnızca bazı düzeltmeler yapmak için oyuncunun yüzünde ve vücudunda yapılan boyama ve değişimler" (TDK, 2019) olarak da tanımlanan makyaj, özellikle insanı merkeze alan ve onu bir obje olarak kullanan tiyatro ve sinema gibi görsel sanatlarda daha fazla ön plana çıkmaktadır. Bu çerçevede tiyatro ve sinema sanatlarına makyaj uygulamalarının en önemli alanları olarak bakılabilir. Ama sinema sanatının tiyatroya kıyasla kadraj, açı, ölçek, devinim ve kurgu gibi kendine has karakteristik özellikleri taşıması eser yaratımında makyajı özel bir anlatı aracı haline dönüştürmüştür. 
Karakter ve tip yaratımında oyuncuların sinema filmlerinde sergiledikleri kișilikler için makyaja ihtiyaç duyulmuştur. Bu ihtiyaç bazen seyirciye aksettirilmeden çok doğal bir şekilde uygulanabileceği gibi bazen de karakterin taşıdığı psikolojik veya fiziksel değişiklikleri betimlemek için belirgin bir şekilde uygulanabilmektedir ama makyaj sadece oyuncunun bir parçası değildir. Nijat Özön'e göre (1985, s. 98) makyaj görüntüyü oluşturan temel öğelerden biridir. Dolayısıyla makyaj uygulamaları sinema sanatında oyuncuların rollerine bürünmesinde kullandığı en önemli tekniklerden bir olmasının yanında gerek sinemasal atmosfer yaratımında gerekse mekân oluşumunda anlatıya yardımcı bir araç olarak da işlev görür. "Sinemada makyaj kozmetik ve plastik olmak üzere temelde iki türe ayrılır. Kozmetik makyaj fondöten, ruj, rimel, allık gibi ürünlerin yardımıyla uygulanan bir makyaj türüdür. Plastik makyaj ise kendine özgü malzeme ve tekniklerle özel etkiler, dışavurumcu ifadeler yansıtmak, farklı yaratımlar ortaya koymak amacıyla yapılır. Canavarlar, yaratıklar, çağdaş ya da mitolojik unsurlar plastik makyajlarla yapılır. Bu nedenle plastik makyajlar sinemanın dış gücünü vurgulayan en etkin görselliklerdir" (Aktaş, 2014, s. 56).

\section{Türk Sinemasında Makyajın Tarihsel Gelişimi}

Türk sinemasında öykülü filmlere geçildikten sinema sanatının öğrenildiği dönem olarak kabul edebileceğimiz 1950'lilere kadar olan sürede tiyatronun Türk sinemasında etkisi çok fazladır. Bu etkileri 1950'liler öncesi yerli filmlerin hem sinematografik anlatım dilinde hem de oyunculuk, dekor, kostüm, makyaj gibi mizansenin yapısındaki tiyatrovari özelliklerinde görmek mümkündür. Dolayısıyla dönemin yerli filmlerdeki makyaj yapısı da tiyatroda kullanılan makyajdan çok farkı değildir. Türk sinemasının ilk yıllarında makyajın bir meslek olarak kabul edilmediğini, makyaja fazla gereksinim duyulmadığını ifade eden Burçak Evren (2014, s. 96), takma sakal ve bıyık, kimi ufak tefek yara bere, saçların briyantinlenmesi, yüze gelişi güzel sürülen pudra, kaş ve kirpiklere çekilen sürmeler, rastıklar vb. uygulamaların yerli filmlerde makyaj adına yapılan başlıca işlemler olduğunu belirtir. Ama Evren'in sözünü ettiği makyaj adına yapılan bu işlemleri de profesyonel makyajcılar değil, aynı tiyatroda olduğu gibi o dönemin oyuncuları gerçekleştirmiştir. 1923 yılında "Ateşten Gömlek" filmiyle Türk sinemasının ilk Türk kadın oyuncusundan biri olan Bedia Muvahhit'in 1973 yılında Yedinci Sanat dergisine vermiş olduğu bir söyleşide makyajın kendileri tarafından yapıldığını şu sözlerle ifade eder:

"Makyaj... Bunun için arkadaşlar birbirine yardım ederdi. Ayrı bir makyöz filan yoktu. Şimdi de, klâsik piyeslerin dışında, herkes ne giyeceğini bilir, kendisi seçer. Makyajını yapar. 0 zaman da filan film deniliyor, ona göre makyajımızı da, giyimimizi de kendimiz yapıyorduk. 'Ateşten Gömlek'te film nedir, sinema nedir, bilmiyordum, bilmiyorduk. Sonradan öğrendik tabii... Sinemanın kendine mahsus özelliklerini, hazırlıklarını da sonradan öğrendik." (Muvahhit, 1973, s.93).

Bedia Muvahhit'in açlklamalarından hareketle Türk sinema tarihimizin ilk makyaj sanatçıları dönemin filmlerinde oynayan ilk tiyatrocu kadın ve erkek oyunculardır diyebiliriz. Bu bağlamda Bedia Muvahhit ve Neyyire Neyir için Türk sinemasının ilk Türk kadın oyuncuları olmalarının yanı sıra Türk sinemasının ilk makyözcüleridir. Ama tiyatro geleneği olarak başlayan, oyuncuların kendi makyajlarını kendilerinin yapması Türk sinemasında kötü bir alışkanlığa dönüşecek ve uzun yıllar bu alışkanlıktan yerli sinemacılar kurtulamayacaktır. Bu kötü alışkanlığın edinilmesinde Türk sinemasında "Tiyatrocular Dönemi" (1923-1939) olarak bilenen dönemin ünlü yönetmeni, tiyatro sanatçısı Muhsin Ertuğrul'un filmlerinde makyaj estetiğini göz ardı etmesinden dolayı önemli bir payı vardır. Yüksel Aktaş (2014, s. 58) "Muhsin Ertuğrul özellikle makyajı önemsemiş, onu sanatının ve meslek hayatının ayrılmaz bir parçası olarak kabul 
etmiştir. Çünkü makyajın yalnızca yüzü belirginleștirmek, hatları vurgulamak ya da mimikleri güçlendirmek için yapılmadığını; insanı tepeden tırnağa değişime uğratan adeta yeniden yaratan sihirli bir yanı olduğunu bilen bir kişi” olduğunu söyler ama Türk sinema eleştirmeni ve tarihçisi Nijat Özön, tiyatrosundaki makyaj uygulamalarını aynen sinemaya taşıyarak "sürekli alay konusu" olan filmlerin doğmasına neden olan Muhsin Ertuğrul'u eleştirmiştir. Özön'e göre (1985, s. 350), sinemaya açıktan gelir sağlayan "ek görev" olarak bakan Ertuğrul ve arkadaşlarının Şehir Tiyatrosu Okulu, "sinemaya olumlu bir katkıda bulunamadıkları gibi, tiyatrodaki kötü alışkanlıklarının çoğunu" sinemaya taşımışlardır:

\begin{abstract}
"Şehir Tiyatrosu Okulu, oyun ya da film olarak çoğunlukla, en bayağı çeşitten Fransız, Alman vodvillerini; Fransız, Alman operetlerini; en ağdalı Alman melodramlarım, yalnız kişi ve yer adlarını değiştirerek alıcı önüne taşıdı. Bunun gibi, tiyatronun bezem, oyun, makyaj, diksiyon, vb. öğelerini de aynı anlayışla olduğu gibi sinemaya getirdi. Tiyatronun derme çatma, kontrplaktı, bezli, boyama bezemleri olduğu gibi alıcı önüne çıkarıldı. Tiyatrodaki makyajın sinemada gülünç düşeceği düşünülmedi; oysa çocukların bile farkına vardıkları bu iğreti saçsakal-bıyık, izleyicilerin sürekli alay konusu oldu. Bu okulun, görünçlükte bile genellikle aşırı, ölçü dışı olan oyunu, sinemada birkaç katıyla kendini gösterdi. Şehir Tiyatrosu oyuncuları hem sinemayı ciddiye almadıklarından, hem de izleyiciyi kolay avlamak amacıyla oyunlarını bir kat daha ağdalandırıyorlar, alıcı önünde oynamanın ayrı bir uygulayıma dayandığını bilmiyorlardı. Otuz kırk yaşındaki kimselerin korkunç bir makyajla altmış yetmiş yaşındaki kimseleri canlandırmaları bu oyunculara göre büyük bir marifet, "kompozisyon yaratmaktı." (Özön, 1985, s. 350).
\end{abstract}

"Şehir Tiyatrosu tekelinin en olumsuz yönlerinden biri de zaten, dikkate değer hiçbir sinema sanatçısı, oyuncusu, uygulamanı yetiştirememesine karşılık, kalabalık bir yönetmenler ve oyuncular ordusu çlkararak etkisini sonraki dönemlerde de sürdürmesi oldu. Kısacası, bu on yedi yıllık ikinci dönem, ilk dönemde atılan olumsuz adımları daha geniş ölçüde kökleştirdi; sinemamızda, sinema çevresinde, sinema izleyicilerinde kolay kolay silinemeyen kötü alışkanlıklar yarattı." (Özön, 1985, s. 350). Özön'ün de belirttiği ve çok kısıtlı imkânların olduğu tiyatrocular döneminin koşulları içinde profesyonel anlamda makyaj uygulamanı da yetişmemiştir ama bu dönem "İ. Galip Arcan, Behzat Butak, Agah Hün, Vasfi Rıza Zobu, Kadri Ögelman gibi oyuncular makyaj konusunda dönemin öne çıkan isimleridir. Yıllar içinde edindikleri profesyonel düzeydeki bilgi ve deneyimlerle yalnız kendilerine değil, başka oyunculara da makyaj yapmışlardır. Kadri Ögelman (1906-1986) makyaj yapım ve uygulamalarında adından en çok söz ettiren kişidir. Alim Şerif Onaran, 'Muhsin Ertuğrul'un Sineması' kitabında Kadri Ögelman'ı Muhsin Ertuğrul'un filmlerinde figürasyona çıkan ve makyaj işlerini üstlenen biri olarak tanıtmıștır. Onun ayrıca 'makyajcılığı Türkiye'de ilk defa sanat haline getiren adam' diye şöhret yaptığını da yazmaktadır.” (Aktaş, 2014, s. 62). Burçak Evren de (2014, s. 100), Zeki Alpan gelinceye kadar makyajı, tümü tiyatro kökenli olan Müfit Kiper, Rıza Tüzün, Kadri Öğelman ve yönetmen Muharrem Gürses"in üstlendiğini söyler ve bu kişilerin yalnızca kendi filmlerinde değil, yardım isteyen diğer yönetmen ve yapımcıların filmlerinde de amatör olarak makyaj yaptıklarını belirtir. Aktaş'a göre (2014, s. 64), söz konusu bu kişiler makyajı "kısıtlı imkânlar içinde kişisel çaba ve özverileriyle edindikleri bilgi ve görgüleri cesaretle uygulamaya” çalıșmışlardır ama bu kişilerin isimleri Sinematürk'ün verilerine göre bir makyaj sanatçısı olarak film jeneriklerinde yer almamıștır. Sinematürk'ün (2019) verilerinde bu sayılı isimlerden sadece 1953 yılındaki "Beklenen Şarkı" filminde makyaj sanatçısı olarak Müfit Kiper'e yer verilmiş, 1950 öncesi yerli filmlerde söz konusu kişilerin isimleri jeneriklerde görülmemiștir. 


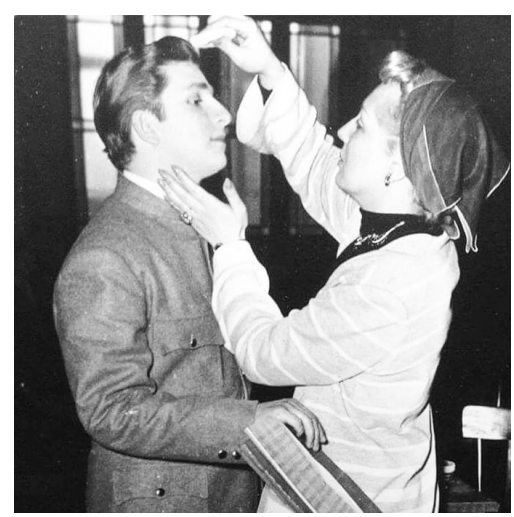

Şekil 1: Cahide Sonku'nun "Beklenen Şarkı" (1953) filminde birlikte oynadiğı Zeki Müren'e makyajyaparken.

Kaynak: http://www.sinematurk.com/film/2113-beklenen-sarki/fotograflar/?sayfa=2)

1940’lı yılların sonlarına doğru Türk sineması Muhsin Ertuğrul dışında yeni yönetmenlerle tanışmış olmasına rağmen tiyatro geleneğinin makyaj uygulama anlayıșı yerli filmlerde devem etmiştir. Burçak Evren'e göre (2014, s. 96) Türk sinemasında ilk profesyonel diyeceğimiz makyaj yöntemlerinin bu dönemde çok az da olsa kullanılmaya başlanmıştır. Faruk Kenç'in "1940 yılında yönettiği 'Yılmaz Ali' filminde oldukça ustaca yapılmış yara izini kadın oyuncularının birinin yüzünde denemesini” örnek makyaj uygulaması olarak veren Evren "bu makyajların kimin ya da kimlerin yaptığı ve nasıl yapıldığını ilişkin bilgilerin bilinmediğini" (2014, s. 96) belirmektedir. Dönemin filmlerindeki makyajları uygulayanların ya da makyajcıların kayıtlara geçmemesinin başlıca nedeni makyaj sanatının o yıllarda meslek olarak çok fazla önemsenmemesidir. 10 Eylül 1948 yılında Yerli Film Yapanlar Cemiyeti (1946) tarafından düzenlenen Türk sinemasının ilk resmi yarışmasında 15 farklı dalda sinema ödüllerinin dağıtılmasına rağmen makyaj hakkında herhangi bir ödülün verilmemiş olması da bu durumu ortaya koymaktadır. ${ }^{1}$

“Sinemacılar Dönemi” (1950-1960) olarak bilinen 1950'li yıllarda Lütfi Ömer Akad'ın öncülügünde, tiyatrodan bağımsız olarak sinema sanatını ve diline öğrenen yeni yönetmenler filmler çekmeye başlamıştır. Bu yıllar ile birlikte yerli film sayıları artışa geçmiş, yıldız oyunculuk sistemi oluşmaya başlamış ve yerli filmcilik bir sektör olarak ortaya çıkmıştır. Yapımcısından yönetmenine, set ekibinden teknisyenine kadar Türk sinemasının uzun yıllar domine edecek olan bu sinemacılar kuşağında da profesyonel anlamda uzman makyaj sanatçlları yetişememiştir. Bu durumun nedenini Yeşilçam'ın ünlü yönetmenlerinden Memduh Ün $(2009$, s. 34) şu sözlerle anlatır: "Yeşilçam'da ellili yıllarda çekilen filmlerde makyör kullanılmazdı. Hem paramız yoktu bu işler için, hem de makyörlerin sayısı aşırı azdı o günlerde. Ya kendimiz yapardık ya da setçilere teslim ederdik bu işlemleri." Memduh Ün'ün "kendimiz yapardık" ifadesine benzer bir açıklamayı ünlü yönetmen Ömet Lütfi Akad'da şu sözlerle yapmıştır: "Vurun Kahpeye" (1949) filminin çekim hazırlıklarını makyaj sorunları olarak anlattığı anılarında "O dönemde negatif filmin kırmızıya olan duyarlılığı nedeniyle oyunculara, benizlerinin koyuluğu açıklığına göre kırmızı bir fondöten sürülüyordu. Yapım yönetmenliği sırasında tanıdığım, Eski Markiz Pastahanesi'nin yanındaki Şark Aynalı Paşajı'nda bulunan berber Melkom'a Settar İçin sakal ısmarlamış, yanı sıra bir dizi de makyaj malzemesi almıştım. Melkom onları nasıl kullanacağımı ayaküstü anlatmıştı. Önüne gelen yüzüne süreceği koyuluğu sormak için bana başvuruyordu, iyice alaya alınmıştım" (Akad, 2004, s. 61). Makyaj bilgisinin bu seviyede olduğu bir ortamda, 1950’lerin çok az sayıdaki film jeneriğinde makyaj sanatçısına yer verilmiş olması, makyajın Türk sinemasında meslek olarak görülmesi adına önemli bir ayrıntı olarak dikkat çekmiştir. 
1950'li yıların makyaj konusunda önde gelen kişisi Zeki Alpan'dır (1908-1992). Aktör, senarist ve yönetmenlik yapan Zeki Alpan'ın makyaja olan ilgisi onu dönemin en önemli makyajcılarından biri haline getirmiştir. Burçak Evren'e göre (2017), Türk sinemasının ilk makyajcısı olan Zeki Alpan, film makyörlügüne (Turknostalji, 2017) 1948 yılında başlamıştır. Ses dergisinde yayımlanan bir röportajda Alpan için "birçok karaktere son şeklini veren, Yeşilçam»ın en usta makyörüdür" (Turknostalji, 2017) ifadesi kullanılmış, "Türkan Şoray, Filiz Akın, Hülya Koçyiğit, Kartal Tibet, Cüneyt Arkın, Ayhan Işık, Ekrem Bora ve daha birçok Yeşilçamlı” oyuncusunun Zeki Alpan'ın usta ellerinden geçtiği belirtilmiştir:

\begin{abstract}
"Aşağı yukarı bütün yıldızlarımızı tarihi şahsiyet haline ben getirdim. Mesela ben Vahdettin ve Abdülhamit oldum. Süleyman Turan'ı Fatih Sultan Mehmet, Cüneyt Arkın'ı Selahattin Eyyubi, İsmail Dümbüllü'yü Nasrettin Hoca haline ben getirdim. Sonra Ulvi Uraz'ın Süleyman Çelebi'deki makyajı benimdir. ...Bu arada makyaj tekniği ile ilgili olarak bir şey fisıldayayım kulağınıza; 'Cami yıkılsa da mihrap yerindedir' diye bir söz vardır. Ben de yıldızların şekli şemalini değiştirirken onları asla antipatik hale koymam, şahsiyetlerini değiştirmem. Dünyada makyaja en az önem verilen yer belki de bizim Yeşilçam... Halbuki makyajın ne demek olduğunu bir bilseler, bir öğrenebilseler, sonuç çok daha başka olacak..." (Turknostalji, 2017).
\end{abstract}

Evren, Zeki Alpan'ın makyaj alanında bir dizi yenilikler getirdiği belirtir. Ona göre "bu yeniliklerin başında ise piyasada yokluğu çekilen ya da karaborsa satılan birçok makyaj malzemesini kendi olanaklarıyla üretmesi gelir. Sinemadan kazandığı parayı mala mülke yatırmayıp Almanya'dan getirttiği pudra, kalem, pat, peruk, maske, bıyık gibi çeşitli makyaj malzemeleri için yine sinemaya yatıran Alpan, işinin tekniğini çok iyi bilen bir uzman olmuştur. Zeki Alpan ünlü yıldızları birkaç dakika içinde güzelleştirir, çirkinleştirir, gençleştirir, yaşlandırır, tarihi filmlerde bağrına ok saplatıp, kılıçla, baltayla kolunu bacağını uçurtarak seyircinin inanabileceği ölçüde kanlı bir şekilde ölmelerini sağlardı." (Evren, 2014, s. 100).

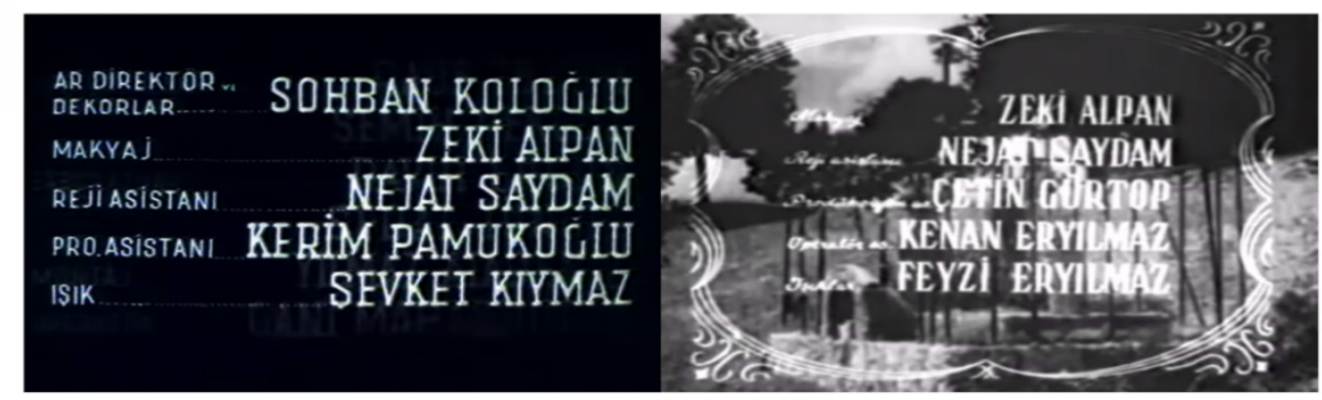

Şekil 2: 1954 yapımı "Şimay Yıldızı" (sol) ve 1956 yapımı "Beş Hasta Var" (sağ) filmlerinin jeneriklerinde Zeki Alpan'ın makyaj sanatçısı olarak isminin yer alması.

Müzeyyen Sevtap Aytuğ'un (2012) Yeşilçam sinemasının ünlü oyuncularıyla yaptığı röportajlardan oluşturduğu "Başlangıcından Günümüze Türk Sinemasında Makyaj" adlı video çalışması Yeşilçam sinemasında makyaj uygulama bilgilerini ortaya koyması bakımından önemli bir çalışmadır. Bu röportajlarda yer alan dönemin oyuncularından Fikret Hakan, 1952 yılında tiyatrodan sinemaya geçtiğinde filmlerdeki makyajları oyuncuların kendilerinin yaptığını, hatta komedyenlerin o zaman makyaj konusunda uzman kişiler olduğunu ama o dönem yapılan bu makyajların sinema sanatına uymayan abartılı makyajlar olduğunu ifade eder. Ayrıca Hakan'a göre o dönemde Türk sinemasında en geride kalan şey makyajdır. Röportajlarda yer alan dönemin yıldız oyuncularından Türkan Şoray da sinemaya başladığı yıllarda film setlerinde makyözlerin olmadığını belirterek, ilk filminde oynadığı veremli kız rolü için yüzüne boyaları kendisinin 
sürdüğünü anlatır. Şoray, o yıllarda bilinçsizce çok makyaj yaptığını, eski filmlerini tekrar izlediğinde bu yapılan makyajların yanlıș olduğunu, doğal olmadığını kabul eder ve filmlerde doğallığın önemli olduğu bilincini edinmesinin kendisi için yıllar aldığını belirtir. Dönemin diğer bir yıldızı Fatma Girik'le yapılan röportajda ise Girik, makyaj konusunda şunları aktarır: "Ben, Hülya, Türkan makyajımızı kendimiz sette yapardık ve bilmezdik nasıl yapıldığını. Beyoğlu'nda küçücük bir dükkân vardı, oraya bazen kalem, pudra gelirdi, hangimiz önce giderse o alırdı. Çünkü sadece bir tane gelirdi yani kapanın elinde kalırdı." Röportajda genelde köy filmlerinde oynadığı için makyaja çok ihtiyacı olmadığını anlatan Fatma Girik, filmlerde kendisine "makyaj yap" denilmediği ifade eder ve meşhur olmadan evvel oyuncu Feridun Karakaya'nın, setlerde artistlere pudrayla amatör makyajlar yaptığını hatırlatır. Röportajdaki bir diğer yıldız oyuncu Hülya Koçyiğit de siyah beyaz film döneminde profesyonel bir makyajcı olmadığını, ancak yara makyajı, yaşlı makyajı yapılacak ya da buna benzer makyajlar yapılacaksa tiyatrodan yardımcı olması için makyaj bilen birinin getirtildiğini bilgisini bizlere aktarır.

1960'lı yıllar, Türk sinemasında film sayılarının rekor sayılara ulaştığı, seyircilerin sinemaları doldurduğu, sinemacıların bol paralar kazandığı altın bir çağ olmuştur. 70’lerin ilk yıllarına kadar devam edecek olan Türk sinemasının bu altın çağında geçmiş makyaj alışkanlıkları devam etmiş, oyuncular makyajlarını önceki yıllarda olduğu gibi ya kendileri ya da setten birileri yapmaya devam etmiştir. Burada sözü edilen makyaj uygulamaları ise genel olarak yaralar ve yara izleri, güzelleştirmek, çirkinleştirmek, yaşlandırmak gibi kozmetik makyaj uygulamalarıdır. Örneğin "Sürtüğün Kızı" (1967) filminde Fatma Girik'in yüzü çok basit makyaj uygulamalarıyla yaşlandırılmıştır (şekil 3). Diğer bir örnek ise "Susuz Yaz" (1963) filmidir. Bu filmde 15 yaşında olan Hülya Koçyiğit (Büyükturan, 2016), kendisinin rol için küçük geldiğini ama kiyafetler, saç ve makyaj ile yaşının büyütüldüğünü söylemektedir. Söz konusu bu makyaj uygulamaları uzun yıllar Türk Sinemasında devam etmiştir ama 1960’lı yıllar profesyonel makyajın filmlerdeki öneminin anlaşılmaya başlandığı yıllar olarak dikkat çekmiştir. Bu durumun başlıca nedenlerinden biri Türk sinemasında farklı tür ve özelliklerde filmlerin yapılmaya başlanmasıdır. Komedi filmleri, ağır melodramlı drama filmleri, aşk filmleri, polisiye filmleri, tarihi kostüme avantür filmleri, yabancı uyarlama filmler (kovboy/ western filmleri), hazretli filmler, süper kahramanlı filmler (çizgi romanlar) bu dönemde popüler olmaya başlamıştır. Yurt dışından uyarlama yapılan filmlerin de bu popülariteye katkısı büyüktür. Bu bağlamda makyaj sanatının önemi tür filmlerinin çeşitlenmesiyle anlaşılmaya başlansa da yerli filmlerdeki makyaj uygulamaları yine amatör düzeyde devam etmiştir. Sinema salonlarının bu yıllarda özellikle yıldız oyuncu etkisiyle dolup taşması ve çoğunluğu siyah-beyaz film olan dönemin yerli filmlerinde siyah beyaz tonlarının amatör makyaj uygulamalarını perdelemesi, zaten yeni kalemler istemeyen dönemin yapımcılarını renkli filmlerin yaygınlaşmasına kadar profesyonel makyaja olan gereksinimini azaltmıştır. Yine de yerli filmlerin tür çeşitliliği amatör makyaj yapan kişilerin yetenek ve deneyimlerini aşan makyaj bilgisini gerektirmiş, dolayısıyla bu işi meslek olarak yapabilen uzman kişilere ihtiyaç duyulmuştur. Evren (2014, s. 100-106) Zeki Alpan'ın asistanlığını yapan Cemel Gonca ve Ehat Alinçe’yi ustaları gibi usta olma konumuna gelmiş dönemin iki önemli makyajcısı olarak sayar. Fikret Hakan (Aytuğ M. , 2012) ellerindeki malzemelerin çok ilkel olmasına rağmen makyaja olan merak ve araştırmaları sayesinde özellikle Cemal Gonca'nın o dönemlerde iyi iş çıkardığını, bilhassa yaralar konusunda iyi uygulamalar yaptığını belirtir. Ayrıca Cemal Gonca kozmetik makyajın haricinde plastik makyajla da ilgilenmiştir: "Filmlerde insan yüzünü değiștiriyordum ama artık bundan bıkmıștım. Bir insanın yüzünü başka bir insana 
benzetebilir miyim diye düșündüm ve plastik makyaj yapmaya başladım. Pudra, vazelin ve yapıştırıcı maddeleri kullanarak makyaj malzemeleri yaptım. Bunu yapmak için iki yıl çalıştım. Evde önce kendime, sonra da eşime ve çocuklarıma makyaj yapıyordum." (Evren, 2014, s. 106).
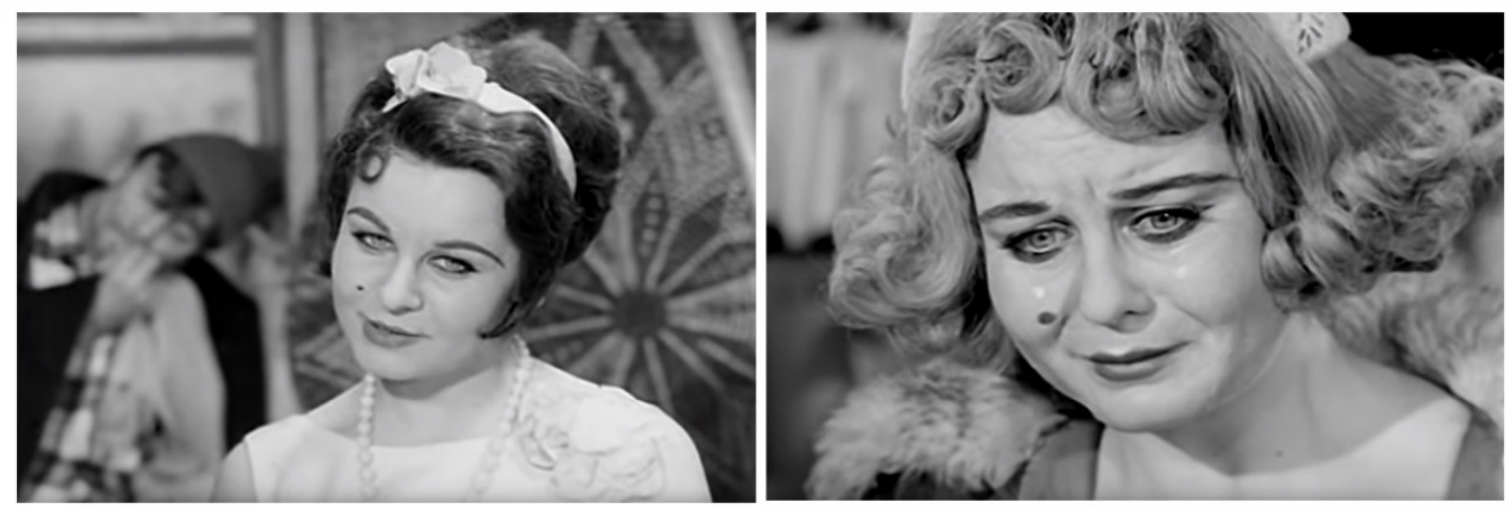

Şekil 3: Zeki Alpan’ın “Sürtüğün Kızı” (1967) filminde Fatma Girik’i makyajla yaşlandırması.

1960’lı yıllar Türk sinemasında önemli bir gelişme de renkli filme geçiştir. Türk sinema seyircisi tarafından çok sevilen bu teknolojik değişim, yerli filmlerdeki makyaj kullanımını doğrudan etkilemiş, yerli filmlerdeki makyaj uygulamalarını geçmişe nazaran daha çok ön plana çıkarmıştır. Siyah beyaz dönemde estetik belirginliği çok az olan Yeşilçam filmlerindeki makyajların, renkli film döneminde ön plana çıkmasıyla hem oyuncuların görselliği hem de sahnelerin gerçekçiliği (yara izleri, kurşun izleri vb.) seyirci tarafından gözle görülür bir biçimde fark edilmeye başlanmış ve bu durum da bir filmin başarılı ya da başarısız olmasını belirleyen başlıca etmenlerden birinin de makyaj uygulamaları olmasını sağlamıştır. Bu bağlamda da bir meslek olarak profesyonel makyajcın önemi artmıștır. Ama dönemin hızlı üretim ve ekonomik koşulları, yapımcıların kar önceliğinin sanatın önüne geçirmesi yerli filmcilikte uzun bir süre daha makyajı çoğunlukla oyuncuların görsel estetik uygulamaları için kullanımına neden olmuştur. Bu estetik kullanımını Aktaş (2014, s. 84), 60’lı ve 70'li yıllarda oyuncuların kendilerine özgü makyaj stilleriyle Türk sinema seyircisinin karşısına çıkması olarak ifade eder. Ona göre bu durum o günkü romantizm duyguları içinde çarpıcı ve göz doldurucu tarzlarıyla olumlu olsa da, "uzman bilgi ve görgüsünden çoğu kez yoksun olan bu makyajlar, kendilerini tekrarlamış ve zamanla demode olmuştur. Çok estetik ya da yüze çok iyi oturmuş olsa da, tüm film türlerinde oyuncuyu yaklaşık aynı makyaj stiliyle görmek, yıllar içinde seyirciye olumsuz yansımış adeta bir yabancılaşma etkisi yaratmıştır."

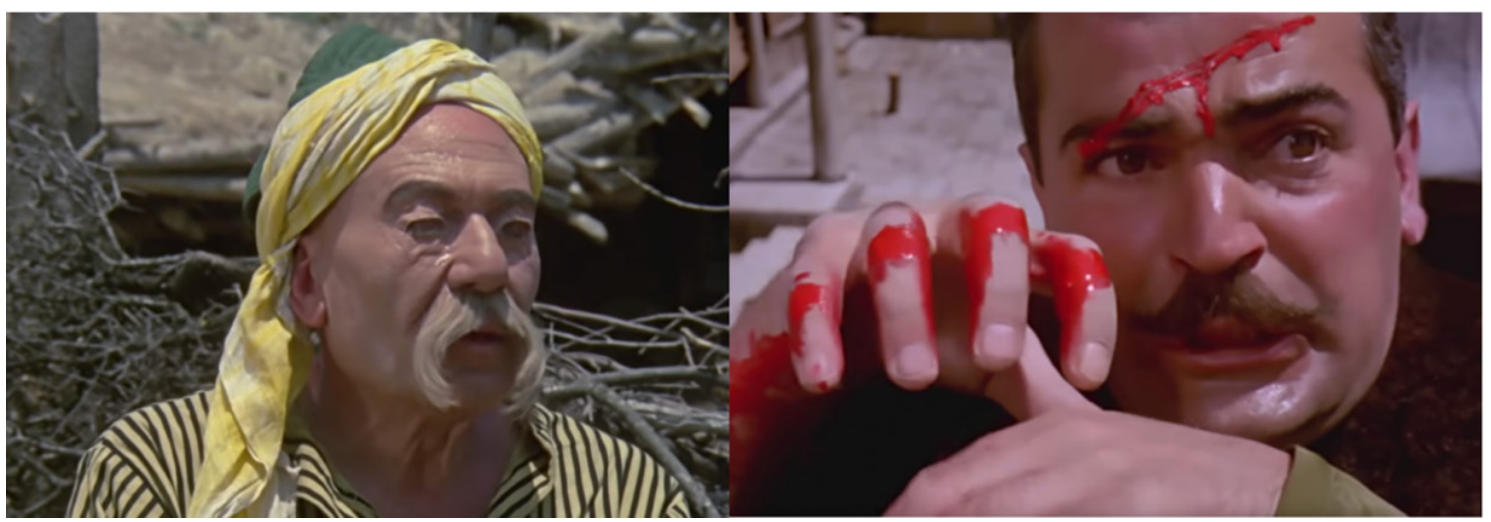

Şekil 4: Cemal Gonca'nın "Köroğlu" (1968) filmindeki makyaj uygulamalarına ait örnekler: Gözüne mil çektirilerek körleștirilen Seyis Yusuf karakteri (sol) ve yüzüne aldığı kılıç darbesiyle yaralanan Bolu beyi karakteri (sağ) 
Türk sineması 1970’li yıllara, 60’larda sürekli artan yerli film sayılarının ivmesiyle hızlı bir giriş yapmış olsa da 70'lerin ortasından itibaren yerli film sektörü özellikle seyircilerin sinema salonlarından uzaklaşmasıyla beraber gerilemeye başlamıştır. $\mathrm{Bu}$ dönemde televizyonun yaygınlaşması, siyasi ve ekonomik istikrarsızlık, sağ-sol çatışmaları ve terör olayları seyircileri sinemadan uzaklaştıran önemli gelişmelerdir ama Yeşilçam'ın temel seyirci kitlesi olan aileleri ve kadınları sinemalardan uzaklaştıran başlıca unsur ülkenin dört bir yanında kendini gösteren erotik film furyasıdır. Ardı ardına çekilen erotik filmler sonrasında ise Türk sinemasında erkek egemen bir seyirci oluşmuştur. Bu bağlamda erotik filmlerin yanı sıra özellikle de "Türklük ve milliyetçilik" temalı tarihi avantür filmler gibi erkek seyircilerin hoşuna giden filmler sinema salonlarının afişlerini doldurmaya başlamıştır. Cüneyt Arkın, Kartal Tibet gibi film yıldızlarının oynadığı, aksiyon ve dövüş sahnelerinin bol olduğu, okların, mızrakların ve kılıçların bolca kullanıldığı bu filmlerde özellikle yara, kan ve kan efektleri başlıca makyaj uygulamaları olarak dikkat çekmiștir ama söz konusu bu makyaj uygulamaları çoğunlukla profesyonellikten oldukça uzak, amatörce yapılmış yüzeysel uygulamalar olarak karşımıza çıkar.

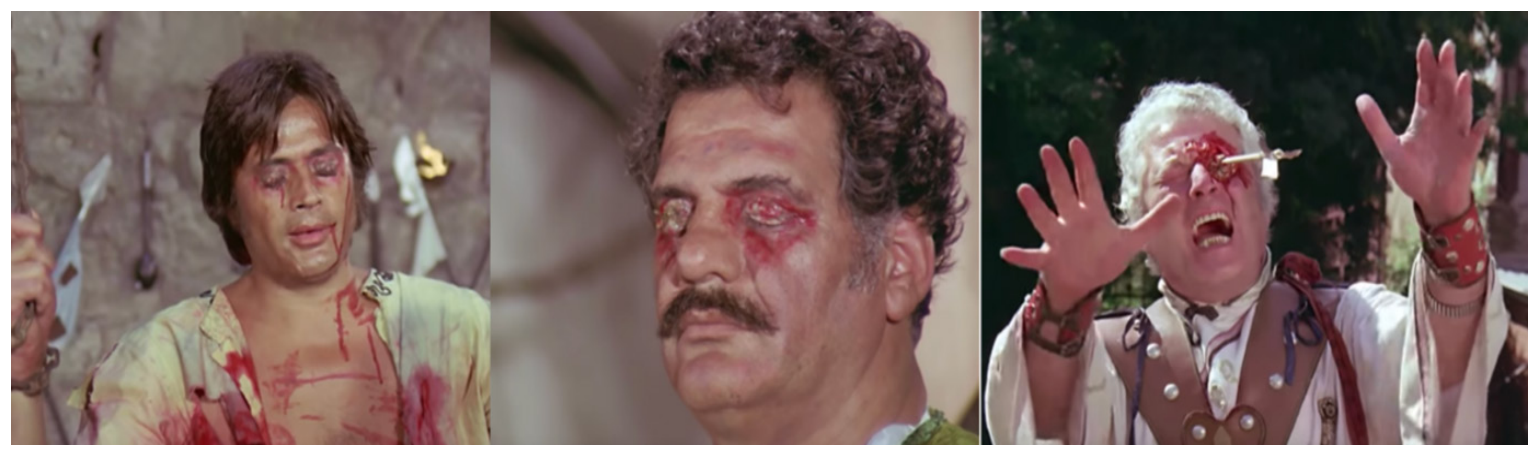

Şekil 5: "Kara Murat Fatih'in Fermanı" (1973)

filmindeki makyaj uygulamaları. Makyaj: Zeki Alpan

Filmlerin çok hızlı üretilip tüketildiği yetmişli yıllarda, makyaj da alelacele işlerle bu hızlı üretim koşullarından nasibini almıştır. Memduh Ün (2009, s. 288-289), 1973 yılında çektiği "Gönülden Yaralılar" filminde 18 yıllık bir zaman akışına karşı oyuncuların yüzlerinde hiçbir değişiklik görmediğini, sadece saçlarında aklar olduğunu ifade ederek iyi bir makyör bulmamalarını sonradan anılarında eleştirmiş ve dönemin aceleciliğini ortaya koymuştur. Ayrıca bu durum hem dönemin koşullarını hem de Yeşilçam'ın makyaja bakışını yansıtması adına önemlidir. Çünkü önceki dönemlerde olduğu gibi 70’li yıllarda da makyaj sanatı film anlatısının ve mizansenin oluşumunda öncelikli bir öğe olarak görülmemiştir. Söz konusu bu durum özellikle yetmişli yılların ilk yarısında yabancı roman ve filmlerden uyarlanarak gösterime giren fantastik filmlerde de görülebilir. Örneğin "Pamuk Prenses ve Yedi Cüceler" (1970), "Ayșecik ve Sihirli Cüceler Rüyalar Ülkesinde" (1971), "Sinderella Kül Kedisi” (1971) gibi prenseslerin, prenslerin, cücelerin, cadıların, büyücülerin olduğu masalsı rüyalar ülkelerini konu alan fantastik filmlerde filmsel atmosferler özellikle kostüm ve makyajlarla gerçekleştirilmeye çalışılmıştır ama makyaj adına çağdaşlarına göre çok daha basit ve gerçekçilikten oldukça uzak uygulamalar ortaya konulmuştur. Bu duruma örnek olarak 1939 ABD yapımı fantastik film "The Wizard of Oz" (Oz Büyücüsü) filminden 32 yıl sonra Yeşilçam'da uyarlanan "Ayşecik ve Sihirli Cüceler Rüyalar Ülkesinde" (1971) filmindeki karakterlerin makyaj uygulamalarını gösterebiliriz. 


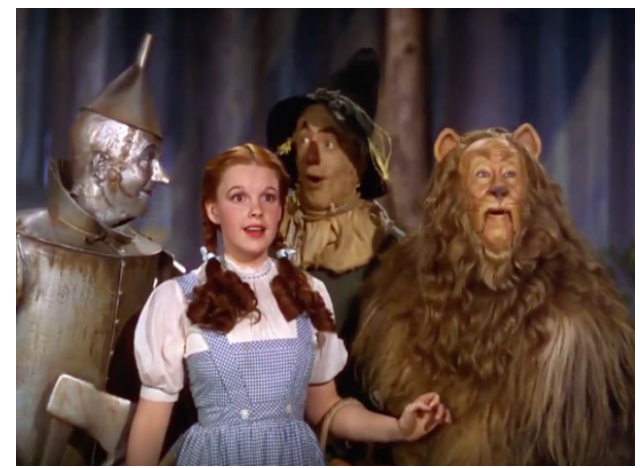

Şekil 6: "The Wizard of Oz" (Oz Вӥуӥсӥsü, 1939)

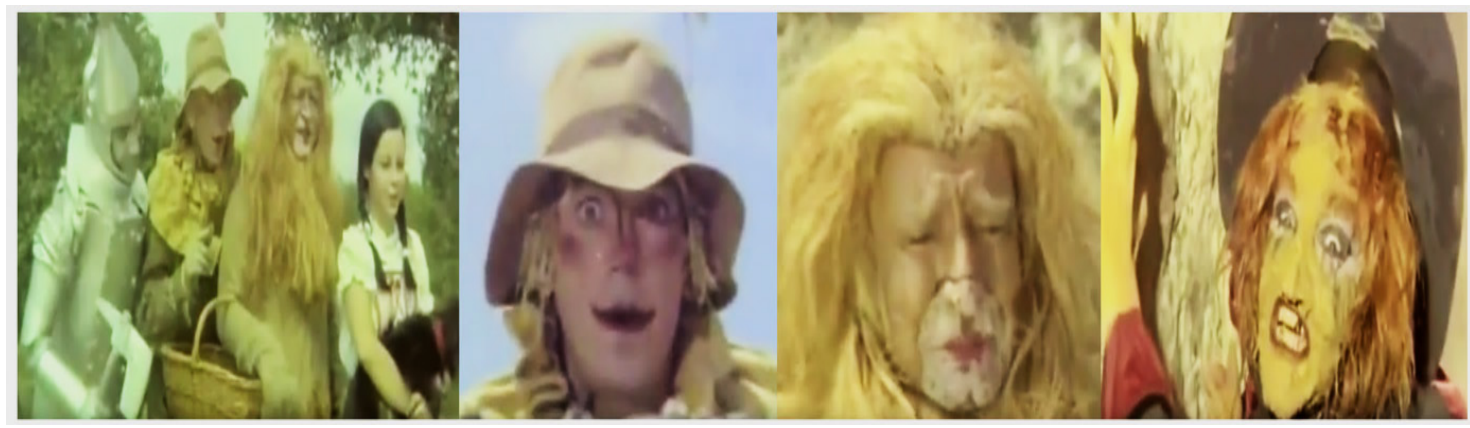

Şekil 7: “Ayșecik ve Sihirli Cüceler Rüyalar Ülkesinde” (1971), Makyaj: Titi Meroni

Yetmişli yıllarda farklı türlerde çok fazla film çekilmesine rağmen sinema makyajı konusunda deneyimli ve uzman kişilerinin sayısı da oldukça azdır. Memduh Ün, 1970 yılında çektiği "Büyük Yemin" filmini değerlendirirken dönemin makyaj koşullarında yerli film üretimine yetişecek yeterli sayıda profesyonel makyaj sanatçısının olmadığını özellikle vurgulayarak bu durumu ortaya koymaktadır: “...Ayrıca yaşlandığında (Fatma Girik) makyajı iyi değil. Biz setlerimizde makyöre gereksinme duymazdık. Setçiler yapardı makyajı ya da oyuncunun kendisi. Çünkü Batı'daki gibi bu işleri becerebilecek insanlar yoktu bizde. Oyuncunun yüzüne çizgi falan çekmeye kalksak, acayip bir insan haline gelebilirdi; bu nedenle dokunmuyorduk. Yalnızca saçlarla oynuyorduk. Saçları önce soba yaldızıyla sonradan da beyaz bir boyayla boyuyorduk." (Ün, 2009, s. 260). Dolayısıyla dönemin yerli film üretimine yetişecek yeterli sayıda profesyonel makyaj sanatçısı bulunamadığı için filmlerde farklı çözüm yöntemlerine başvurulmuştur. Örneğin Türkiye'de çok büyük ilgi gören Wang Yu'nun “Kolsuz Kahraman” (1967) filminin Türk versiyonu olan "Tarkan Güçlü Kahraman Kolsuz Kahramana Karşı” (1973) filmi için Mısır'dan makyör getirilmiştir (Turknostalji, 2012). Benzer bir durum Metin Erksan'ın "The Exorcist" (1973) filminden uyarladığı 1974 yapımı "Şeytan" filminde vardır. Metin Erksan'ın Yüksel Aktaş’la yaptığı röportajda “Şeytan” filminin makyajları için İngiltere'ye gittiğini, İngiltere'de aldığı malzemeler ve teknik bilgileri “Şeytan” filmindeki makyajlarını yapan kişiye kendisinin tarif ettiğini ifade etmiştir (Aktaş, 2014, s. 80). 


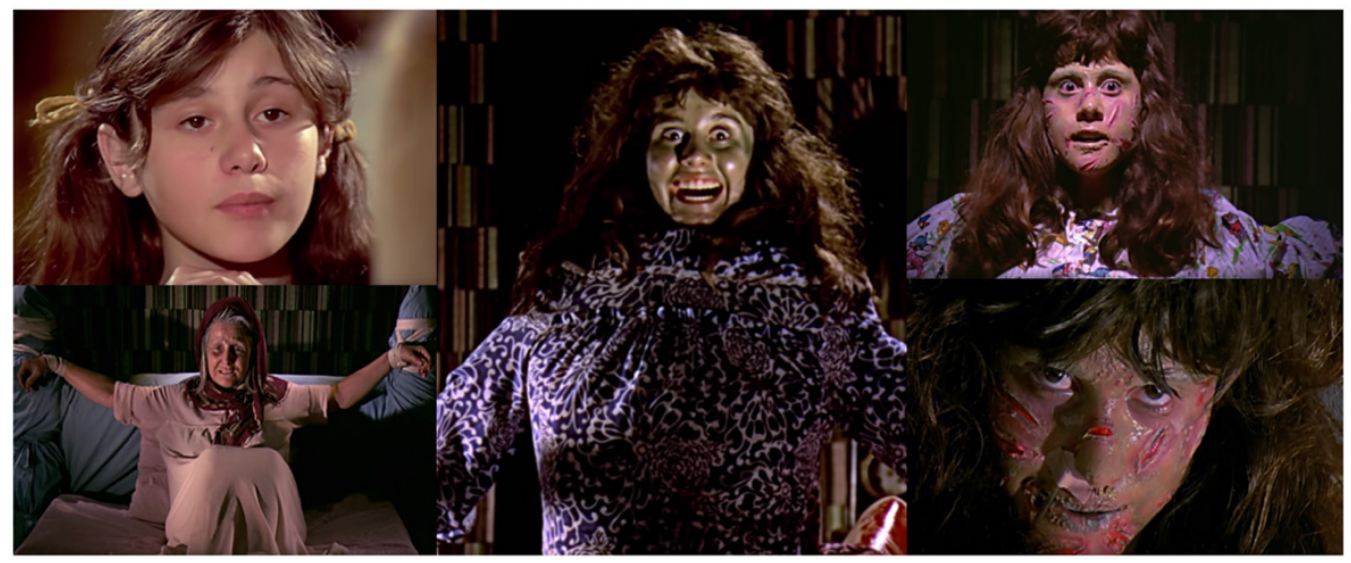

Şekil 8: "Şeytan" (1974) filmindeki kozmetik ve plastik makyaj uygulamalarından kareler (makyaj sanatçısı bilinmiyor)

Yetmişli yıllarda Zeki Alpan, Cemal Gonca gibi makyaj konusunda kendini geliştirmiş kişilerin yanında birkaç filmin jeneriğinde Titi Meroni, Esin Özyacısı gibi yeni isimler de görülür ama aslında Türk sinemasında makyaj sanatına önemli katkılar sunacak eğitimli kişiler dönemin sonlarına doğru ortaya çıkmıştır. Bunlardan en önemlileri ise eğitimlerini yurtdışında almış olan Yavuz Birsen ve Oya Tolga'dır. Oya Tolga Fransa'da Sinema Televizyon alanında makyaj sanatçısı eğitimi almış ve bu konuda uzmanlaşmış biridir. 1970'lerin sonlarına doğru mesleğe başlayan Tolga, dönemin ortamını "Hayat Güzeldir" televizyon programındaki röportajında şöyle anlatmaktadır:

\begin{abstract}
İlk Almanya'da bir çekim makyajı yapmıştım çok olay oldu. Çünkü o zamana kadar herkes kendi boyanıp giderdi. Yeșilçam öyle gelişmiști. Makyajın varlığından kimsenin haberi yoktu. Makyaj mı, nedir, süpervizör nedir, kimsenin bildiği yoktu. Ben öyle başladım. Eskiden makyaj Türkiye'de Yeşilçam'da yara, yanık, kavga dövüș sahnelerinde bazı kanlar falan filandı. Onlarda ne kadar başarılı olurdu onları bilemiyoruz tabii şimdi ama görüyoruz bazıları pek başarılı değil, bazıları de fena değil, güzel olanlar da var aralarında ama pek doğaçlama yapılan bir şeydi." (Tolga, 2016).
\end{abstract}

Türk sinemasında makyaj sanatının profesyonel anlamda ilk yapan kişilerden biri olan Oya Tolga, aynı programda "sinemacılarla ilişkilerim iyi olmasına rağmen, onları da çok iyi tanıyıp dostluklarım olmasına rağmen, yaptığım işlerde çok iyi olmasına rağmen devamlı, sürekli bir çalışmamız olmadı" demektedir. Tolga, bu durumu yerli filmlerin maddi koşullarına bağlamaktadır:

\footnotetext{
“Türkiye'de sinema sektörü kendi içinde kendi kendini yaşıyor. Bizler onlara ulaşamıyoruz. Ben bir sinema sektörüne girip çalışamadım, mesleğim olmasına rağmen, sinema Televizyon teknik makeup artist olmama rağmen, aynı zamanda süpervizörlük yapmama rağmen ben onlarla çalışamadım. Neden? Çünkü beni talep etmediler maalesef. ... Daha çok maddesel olarak tercih etmediler. Çünkü ben ne kullanacağım malzemeden ne kendimden fedakârlık edemedim. Çünkü bu iş böyle yapılır biliyorum, başka türlüsünü bilmiyorum nasıl yapılması gerekiyorsa en iyisini yapmak istediğim için biraz masraflı geliyorum herhâlde. Bu benim yaralarımdan biridir." (Tolga, 2016)
}

Dönemin bir diğer önemli makyaj sanatçısı ise Yavuz Birsen'dir. Corci olarak bilinen Yavuz Birsen Burçak Evren'e (2014, s. 100-118) göre, Türk sinemasında makyajı çağdaş bir konuma getiren ve bu alanda üne kavuşan kișidir: "Corci makyajı bir meslek haline getirmiş, bu konunun eğitimini alarak uygulamış bir kişidir. Ayrıca sinemamızda, bir filmin oluşumunda makyajın ne denli önemli olduğunu kanıtlama misyonunu da üstlenmiş, uzun yıllar bu alanda tek adam olarak çalışmıștır." Evren (2017), Corci ile beraber Türk 
sinemasında makyajın sadece çirkinleștirmenin ve güzelleştirmenin ötesinde karakter yaratma olgusunun ortaya çıktığını ifade eder.

\begin{abstract}
“Sinemada reel makyaj çok önemlidir. Çok iyi kullanmak lazım... 35’lik çekiyorsan filmi bilmen lazım... Film banyosunu bilmen lazım... Objektif bilmen lazım... Sinemayı, laboratuvarı bilmen lazım... Şimdi şu dönemde, hangi kamerayla çalışacaksın, bilmen lazım, bu bir... Hangi objektifle çalışacaksın, bu iki... Senaryoyu bilmen lazım, okuman ezberlemen lazım, üç! Sahne sahne ne yapman lazım bilmelisin. Bir kere, bağlantılar çok iyi yapılmalı... Bir sahnenin arkasından gelen sahnede de, o makyajın birebir aynısını yapman gerekiyor. Bunu takip etmen gerekiyor, çok ciddi bir konu. Sinemada makyaj, hikâye de yaşayan kişinin yaşantısını makyajla vermektir. Sabah kalktığı zamanki halini, üzgün olduğu zamanı verebilmektir." (Evren, 2014, s. 122).
\end{abstract}

“Türkiye, 80’li yıllara yetmişlerin ortalarında başlayan toplumsal olayların şiddete dönüştüğü bir kaos ortamıyla giriș yapmış, sağ-sol çatışmaları, terör olayları, ekonomik sorunlar ve siyasi istikrarsızlık Türkiye'yi 12 Eylül darbesine ve ardından dokuz yıl sürecek bir askeri yönetimin içine sürüklemiştir. Siyasal ve toplumsal olaylardan etkilenen bu dönem Türk Sineması'nda yerli filmlerin hem içerik hem de biçim yapısında önemli kırılmalar yaşanmıştır. Yeşilçam sinemasının aile melodramları ve güldürüleri yerine, mikro düzeyde kişiselleşmiş ve bireysel anlatımları ön plana çıkan yeni bir anlatım dili doğmuştur" (Zengin, 2017). Televizyonun etkinliğinin arttığı bu yıllarda, videolar yaygınlaşmış, arabesk filmler popüler bir tür olarak dikkat çekmiş, dönemin ortasından sonra yeni bir konu olarak 12 Eylül temalı filmler yapılmaya başlanmıştır. Sinema seyircisinin oldukça azaldığı bu dönemde, önceki yıllara göre yerli film üretiminde de düşüş yaşanmıștır. 1990'lar ise Amerikan filmlerinin salonları kapladığı, çok az yerli filmin çekildiği yıllar olarak dikkat çeker. Bu yıllarda bağımsız sinema ya da sanat filmi olarak nitelendirilecek filmler çeken yeni sinemacılar amatör oyuncu kullanımları, özgün senaryo anlatımları ve çekim teknikleriyle adlarından söz ettirmişlerdir. 90'lı yılların yarısından itibaren özellikle de seyirci rekoru kıran "Eşkıya" (1996) filminden sonra ise yerli sinemadaki kriz, seyircilerin tekrar yerli filmlere gelmeye başlamasıyla kendini toparlamaya ve yeni bir Türk sineması ortamının doğmasına neden olmuștur.

Seksenli ve doksanlı yılların filmlerdeki makyaj anlayışına baktığımızda toplumsal gerçekçi akımından da hareketle filmlerde ağırlıklı olarak anlatılarına uygun sade ve yalın makyajların kullanıldığını sinema karakterlerinin doğal halleriyle sinema perdelerine yansıtıldığını görürüz. Çünkü "toplumsal dönüşümün etkileri ve darbenin yarattığı boşlukta sinema bireyin iç dünyasına, kişisel arayışlarına, içsel yolculuğuna yönelir; daha çok da yenilmiş, yanılmış, hayal kırıklığı yaşamış, yalnızlaşmış 'aydın bireyin' içsel/düşsel yolculuğuna. Kişisel filmler, kadın filmleri, bireyin sorunlarına yönelen, iç yolculuğunu, bunalımlarını ve arayışlarını yansıtan filmler bu ortamın ürünleridir." (Kara, 2013). Özellikle Yeşilçam'ın yıldız oyuncuları Türkan Şoray, Hülya Koçyiğit, Tarık Akan, Kadir İnanır, Kemal Sunal, Yılmaz Güney gibi yıldızların filmlerinde söz konusu bu sade ve doğal makyaj kullanımlarını görmek mümkündür. Örneğin dönemin ünlü oyuncularından Kadir İnanır birçok farklı türde filmde oynamasına rağmen çoğunlukla aynı saç, bıyık ve makyajla kamera karşısına geçmiştir. İnanır'ın, filmlerdeki tek dikkat çeken değişikliği ise bazı filmlerinde sakallı olmasıdır. Bu filmlerin aksine erotik unsurları çokça barındıran dönemin kalitesiz, aksiyon, macera, polisiye ve fantastik filmlerindeki makyajlar ise "gülünç" seviyesindeki amatör uygulamalar olarak karşımıza çıkar.

Yeşilçam'ın değişen yapımcılık anlayışı ve dönemin kötü mali koşullarıyla üretilen amatör makyaj uygulamaları özellikle yönetmen Çetin İnanç'ın filmlerinde ve Cüneyt Arkın'ın başrolünü oynadığı filmlerde sıklıkla karşımıza çıkmaktadır. Örneğin 1983 yapımı "Vahşi 
Kan” filmine bakılabilir. Yönetmenliğini Çetin İnanç'ın yaptığı, başrolünde Cüneyt Arkın'ın oynadığı bu sıra dışı film, ABD yapımı Rambo serilerinin ilki olan 1982 "First Blood" (İlk Kan) filminden uyarlanmıştır ama filmin içinde uyarlanan filmden bağımsız olarak zombiler olmak üzere birçok farklı karakterler ve mizansenler vardır. Filmin sonradan popülaritesini sağlayan "çok kan akacak, vahşi kan akacak, kan, kan..." repliğinden de anlaşılacağı üzerine filmde, kırmızı boyalarla yapılan, gerçekçilikten uzak bolca kan efekti makyaj uygulaması amatörce kullanılmıștır. "Vahşi Kan" filminin ilk kopyasını bir festivalde 31 yll sonra izleyen yönetmen Çetin İnanç'ın (2014), "bu filmi 31 senedir seyretmemiştim. Yaptım, sinemalarda gösterildi, ilk kopyayı bile seyretmedim. Çünkü vaktim yoktu, haftada 4 film çekiyordum" sözleri hem söz konusu amatörlüğün nedenini açıklamakta, hem de dönemin sinema ortamını yansıtmaktadır.

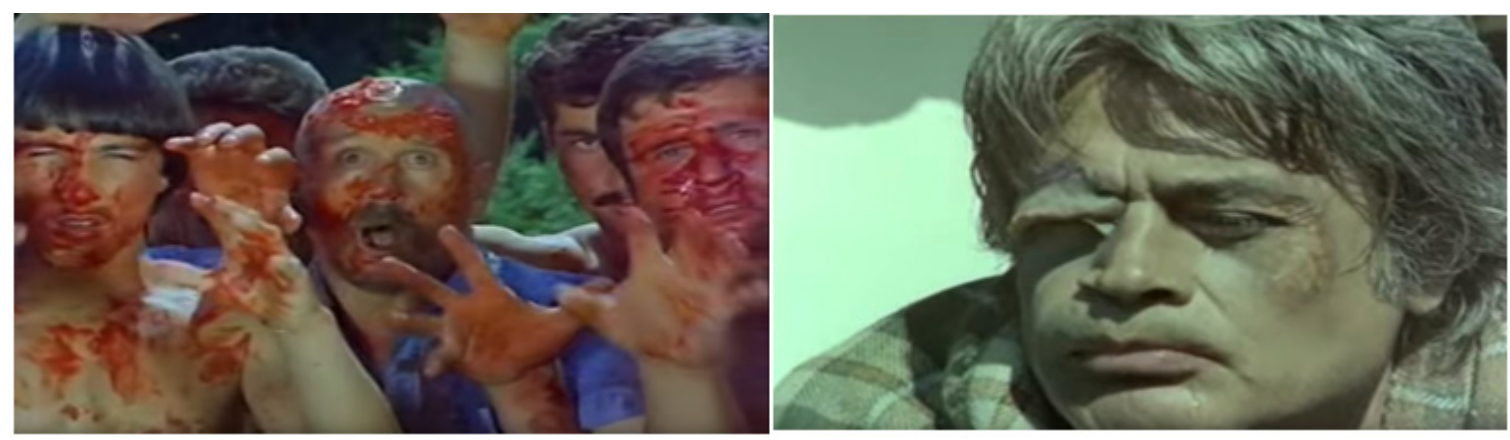

Şekil 9: Yönetmenliğini Çetin İnanç’ın yaptığı iki farklı filmdeki makyaj uygulaması: "Vahşi Kan" (1983) filmindeki Zombiler (sol) ve "Dört Yanım Cehennem"

(1982) filminde göz yaralanması (Makyaj sanatçıları bilinmiyor).

Seksenli yıllar Türk sinemasında makyaj, gelişen bir olgu olarak dikkat çekmiş ve bu alanda uzman yeni makyaj sanatçıları yetișmiștir. Buna göre dönemin yerli film jeneriklerinde yer alan başlıca makyaj sanatçıları şu kişilerdir: Ayten Yeşil Çorbacıoğlu, Cüneyt Ballı, Mediha Şafak, Leda Seril, Abdullah Gonca, Suzan Kardeș, Oya Tolga, Neriman Kardeş, Evin Soley, Sahra Yıldız, Nevin Barut. Bu sanatçllara rağmen dönemin birçok yerli film jeneriğinde bir uzmanlık alanı olarak makyaja yer verilmediği görülmüștür. $\mathrm{Bu}$ durum Yeşilçam sinemasının kötü bir alışkanlığının devamı olarak yorumlanabilir. Söz konusu bu kötü gelenek karakter ve tip makyajının başarılı örneklerinin verildiği 90’lı yıllar Türk sinemasında son bulmuş ve dönemin tüm yerli film jeneriklerinde makyaj mesleği ve sanatçısı yer almıştır. Böylelikle Türk sinema tarihinde makyajın bir meslek olarak tam anlamıyla kabul görmesi doksanlı yıllarda gerçekleşmiştir. 1990’lı yıllardaki filmlerin jeneriklerine baktığımızda 80'li yıllarda ismi geçen makyaj sanatçılarına ek olarak yeni isimlerin sektöre girdiğini görmekteyiz. Buna göre, Perizat Dumrul, Nevin Kuzucu, Nevin Cangüler, Zübeyde Erden (Corci'nin asistanı), Derya Ergün, Rengin Altan, Şermin Mikar, Sevinç Uçar, Hüseyin Üküm, Sakine Keskin, Zühre Ustaşanverdi, Selma Pısırlı, Belgin Ömürdağ dönemin yeni makyaj sanatçlarıdır.

\section{Televizyon ve Plastik Makyajın Gelişimi}

Türkiye'de 1970'li yıllarla birlikte adını duyurmaya başlayan 80'lerde ise gelişen ve yaygınlaşan televizyon, sinemada yllarca önemsenmeyen ve profesyonel anlamda gereksinim duyulmayan makyaja önemli bir aşama kazandırmıştır. TRT’nin televizyon programlarına başlamasıyla birlikte uzman makyajcılara ihtiyaç duyulması ve sonrasında kadrolu alımlar yapılması, alınan kişilerin de makyaj konusunda eğitilmesi sözünü ettiğimiz önemli aşamalarının ilk adımlarıdır. Burada yetişen makyaj sanatçılarının bilgi ve becerileri kısa sürede yerli film sektörünü de etkileyecektir. TRT'nin ilk yıllarındaki 
önemli dizilerin makyaj sanatçısı Cüneyt Ballı ile yapılan görüşmede, TRT’nin yapmış olduğu atılımları ve görsel personellerinin yurtdışına gönderip eğitmesiyle birlikte TRT’nin öncülüğünde Türkiye'de sinema sektörünün ayrı bir yapıya kavuştuğunu ve Türk sinemasının biraz daha Avrupai, daha modern olmaya başladığını söylemiştir. Böylelikle Türkiye'de bir kademe atlandığını vurgulayan Ballı, bu kademenin de "otomatikman makyaj konusunda daha doğru kişilerin öne çıkmasını sağlamıştır" (Kişisel görüşme 25 Temmuz 2019) diyerek, burada ilk adımın Corci ile başladığını, arkasından kendisinin ve Derya Ergün gibi bir iki isimle devam ettiğini ifade etmiștir.

Yetmişlerin başında Türkiye'de makyaj eğitimi olmadığı için İngiltere'ye gidip makyaj eğitimi alan TRT televizyonunun ilk makyözcülerinden Sema Tuğsal (2016), kendisiyle birlikte, Ayșe Temiz, Kıbrıs asıllı Nihal Münsıf (Nil Burak adıyla bilinir), Evin Soley ve Zübeyde Erden'in TRT’nin ilk makyajcıları olduğunu ifade etmiştir. “Kaynanalar, Azap, Suçlu Kim?, Murat Davman gibi televizyonun ilk dizileri, Bizim Sokak gibi televizyonun ilk dönem çocuk yapımları ile sayısız, açık oturum, müzik eğlence programlarında görev alan" Tuğsal, TRT'deki ilk yılları şu sözlerle anlatır:

\begin{abstract}
"Televizyonun ilk yıllarında bazı kadrolar sorun oluyordu. Devlette; kameraman, montajcl, resim seçici, makyajcı gibi kadrolar olmadığı için sınavla işe alınan, gece gündüz yayın hizmetinde çalıștırılan birçok kişiye maaş verilemiyordu. Tek makyajcı olarak, haftada üç gün yayın ve bunun dışındaki tüm programlarda görev alan ben de altı ay kadar ücretsiz çalıştım, sonra akitli oldum ve ardından da 1973 yılı Mart ayında, TRT televizyonu ilk iki makyajcısından birisi olarak kadroya girdim. Zübeyde daha sonra İstanbul'a atandı, Ankara'da uzun süre tek kaldım ardından Ayșegül Gür ve diğer arkadaşlarım makyaj konusunda hizmet verdiler." (Tuğsal, 2016).
\end{abstract}

TRT Ankara Televizyonu'nun ilk makyaj sanatçllarından Gülsen Doğancı da TRT’nin yetiştirdiği eğitimli kişilerdendir. Doğancı (2014), TRT’ye spiker olarak işe girdiğini ama makyaj departmanı olmadığı için kendisinin makyaja kaydırıldığını ve eğitim için Almanya'ya gidip ZDF merkezinde bir yıl eğitim aldığını ve döndüğümde televizyon makyajı konusunda hayli bilgili olduğunu ifade eder. Bu bilgilerden hareketle aynı dönem içinde Yeşilçam sinemasında çalışan makyaj sanatçıları kendi gayret ve imkânlarıyla mesleği sürdürürken, TRT makyaj konusunda uzman bir kadronun yetişmesini sağlamıș ve profesyonel anlamda makyajın gelișmesine katkı sunmuştur. TRT’nin bu katkılarını makyaj malzemelerinin temini ve uygulamalarından da görebiliriz. Sema Tuğsav'ın, TRT'de ilk kez uyguladığı karakter makyajını anlatırken dile getirdiği sözler TRT'nin makyaja yapmış olduğu yatırımlarını da ortaya koymaktadır (Tuğsal, 2016):

\footnotetext{
"Televizyonculukta sadece görüntü makyajı değil, plastik makyaj denilen tip değiştirme de yapılması gerekir. 1975 yılında yayımlanan Hafta Sonu programında 'Maymun Ailesi' adlı dizide, Macit Flordun'a uyguladığım plastik makyaj büyük olay oldu. Eldeki malzeme ile yaptığım makyajla ilgili olarak sanatçı röportajlarında benim çalışmalarımı anlattı, basın bu işin üstüne gitti ve bundan sonra ben 1976 yılı başında ZDF'nin kurslarına katılmak üzere Almanya'ya gönderildim. Bundan sonra, çeșitli programlarda kullanabilmek için, özel izinle yurt dışından Lateks getirttik, kullanma yetkisi sadece bendeydi. Bu malzemeyle karakter makyajını ilk defa bir şaka programında uyguladık. Cumartesi günleri öğlenden sonra yayınlanan Hafta Sonu programında ilginç buluşları olan Emin Metin Tuncer yine bir ilke imza attı. O günlerde çok büyük bir heyecanla izlenilen 'Kaçak' adlı dizideki Doktor Richard Kımble'ın bir benzerini bulmuş. Esas olarak bir benzerlik var ama biz onu 'lateks' kullanarak daha da benzer hale getirdik. Bütün ülke bu diziyi merak ederken, Doktor Kımble, bir cumartesi günü TRT’nin Hafta Sonu programına konuk olmuştu."
}

TRT’nin makyaj sanatına vermiş olduğu değeri, makyajı bir meslek olarak konumlandırmasından da anlayabiliriz. Türk sinemasında doksanlı yıllara kadar yerli 
filmlerin başlangıç ya da bitiş jeneriklerinin çoğunda makyaj ve makyaj sanatçısına yer verilmezken, Türkiye'nin ilk televizyon kanalı olan TRT'nin ilk dönem program ve dizi jeneriklerinin çoğunda makyaj sanatçısı özellikle belirtilmiștir. Örneğin 1974 yılında yayınlanan ilk yerli dizilerden "Darısı Başınıza" adlı dizisinin makyajcısı Gönül Doğuş; 1979 yılında yayınlanan "Kiralık Konak" adlı dizinin makyajcısı Sema Özaras; 1984 yılında yayımlanan "Küçük Ağa" dizisinin makyajcıları Cemal Gonca ve Abdullah Gonca; 1986 yılında yayınlanan "Çalıkuşu" dizisinin makyajcısı Abdullah Gonca; 1987 yılında yayınlanan "Belene" dizisinin makyajcıları Suzan Tombak ve Neriman Kardeş; 1988 yılında yayınlanan "Kuruluş Osmancık" dizisinin makyajcısı Cüneyt Ballı; 1988 yılında yayınlanan "Yaprak Dökümü" dizisinin makyajcıları Corci ve Murat Urlalı olarak jenerikte yer almışlardır. TRT’nin makyaj mesleğini bu şekilde önem atfedip konumlandırması yıllardır yerli filmlerin jeneriklerinde düzenli olarak yer almayan makyaj mesleğini, sürekli hale gelmesine katkı sunacaktır.

1980'lerin sonlarından itibaren açılan özel kanallar, televizyon kanalları arasında rekabet ortamının oluşmasını sağlamış, söz konusu bu rekabet kısa sürede televizyon programlarında görülen tür çeşitliliğini de beraberinde getirmiştir. Kozmetik makyajın ötesinde karakter oluşumunda plastik makyajın ön plana çıktığı bu yıllarda, genel televizyon izleyicilerinin en çok ilgisini çeken programlar ise televizyon dizileri ve filmleridir. Dolayısıyla ilk profesyonel plastik makyaj uygulama örneklerini de televizyon dizi ve filmlerinde görülmüştür. Burada öne çıkan yapımlar ise TRT’nin ilk dönem dizileridir. TRT’nin yayınlandığı yıllarda oldukça ilgi gören Türk romanlarından uyarlanan dram, savaş, tarih temalı dizilerinde, kozmetik makyajın ötesinde profesyonel anlamda plastik makyaj teknikleri de kullanılmıștır. Bu profesyonel plastik makyaj kullanımlarının önünü açan öncü makyaj sanatçısı Türkiye'de Yavuz Birsen'dir. Sinema ve televizyon sektörüne 70’lerin sonlarında giren Birsen'le yapılan görüşmede, “1979’da benim gelmemle Türk sinemasına plastik makyaj geldi" (Kişisel görüşme 20 Temmuz 2019) diyerek öncesinde böyle șeylerin bilinmediğini söylemiștir. Görüșmede kendisinin ilk plastik makyajı bir reklam filminde yaptığını belirten Birsen, 1979 yılında TRT'nin yaptığı "İbiş'in Rüyası" televizyon filminde rahmetli Münir Özkul'u gençleştirmesini ilk plastik makyaj örneği olarak anlatır. Sonrasında ise 1989 yılında TRT'de yayınlanan Cahide Sonku'nun hayatını anlatan "Cahide" dizisinde de plastik makyaj kullandığını söyleyen Birsen, bu dizide, plastik makyaj kullanarak Cahide Sonku'nun son yıllarını yansıttıklarını, ama bu filmlerden önce sektörde böyle şeylerin olmadığını ve bilinmediğini özellikle ifade eder. Ama Yeşilçam sinemasında plastik makyaj uygulamalarına az da olsa rastlanmaktadır. Bu anlamda özellikle Metin Erksan'ın “Şeytan” (1974) filmi başarılı bir örnektir, bu örneğin haricinde Cemal Gonca'nın yaptığı bazı uygulamaların yanında, küçük çaplı amatör düzeyde plastik makyaj uygulamaları da yapılmıştır ama profesyonel anlamda plastik makyaj uygulamaları televizyon dizileri ve programlarında ortaya çıkmıştır. Burçak Evren’e göre ise “1989 yılında Osman Sınav'ın Kültür Bakanlığı için çektiği 'Yunus Emre' filmi, 1991 yılında yayınlanmaya başlayan TGRT’nin 'Kurdoğlu' film serileri: 'Kurdoğlu/Osmanlı Bedel İster' (1991), 'Kurdoğlu/ Sancağın Ordusu' (1992) ve 'Kurdoğlu/Biz Bu Yola Baş Koyduk' (1992) filmlerinde ilk plastik makyaj uygulamaları yer almıştır." (Evren, 2014). 

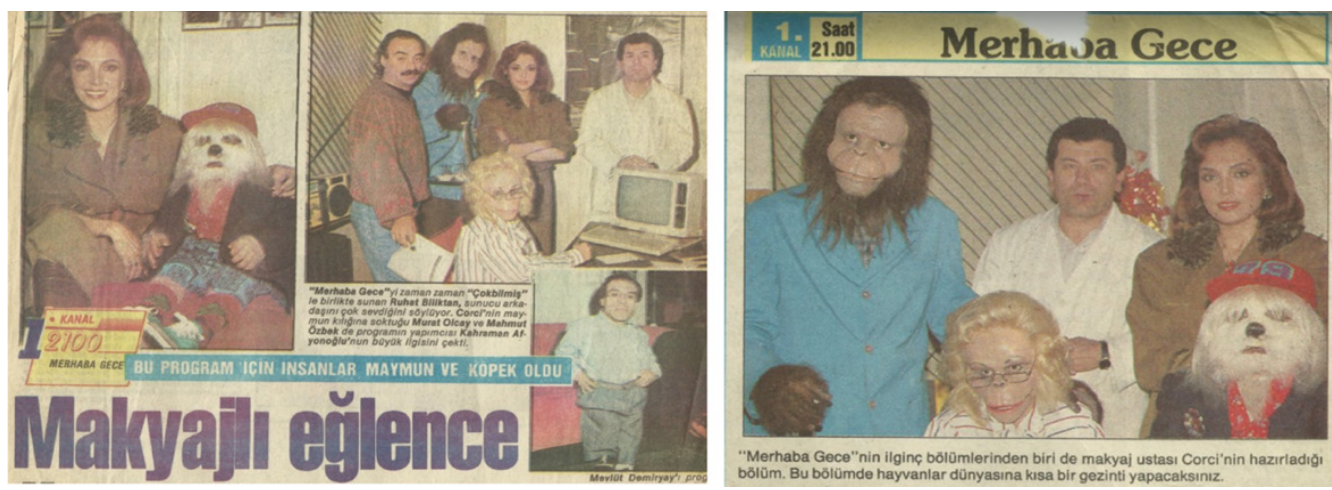

Şekil 10: 1987'de TRT'de yayınlanmaya başlayan "Merhaba Gece" programı için Corci'nin yapmış olduğu plastik makyajların dönemin gazetelerinde haber olması. (Kaynak: Yavuz Birsen arşivi)

Türkiye'de makyaj olgusunu ve plastik makyajı popüler hale getiren kişilerin başında Levent Kırca gelir. 1988'de ilk bölümü yayınlanan “Olacak O kadar” programında farklı tip ve kişilikleri canlandıran Levent Kırca ve arkadaşlarının skeçleri seyirci tarafından çok sevilmiş, böylelikle bu program uzun yıllar çeşitli kanallarda devam etmiştir. "Olacak 0 kadar” programının özellikle doksanlı yıllardaki bölümlerinde Levent Kırca’nın plastik makyaj yöntemleriyle siyasi figürleri canlandırması ve politik taşlama parodilerine konu etmesi Türkiye'de plastik makyaj tekniğini de popüler hale getirmiştir. Levent Kırca'nın plastik makyaj bilgisi ise Yavuz Birsen'den aldığı eğitimlerle olmuştur. Levent Kırca'ya bir dönem malzeme desteği verdiğini ifade eden Birsen "malzemeyle beraber neyi ne yapması gerektiğinin eğitimini verdik" (Kișisel görüșme 20 Temmuz 2019) diyerek plastik makyaj konusunda Kırca'yı bilgilendirdiğini açıklamıştır.

Türkiye'de makyaj olgusunu popülerleştiren bir diğer gelişme de Türkiye Cumhuriyeti'nin kurucusu Mustafa Kemal Atatürk'ün televizyon dizilerinde ve filmlerde canlandırılmasıdır. Çünkü dizi ve filmlerde Atatürk rollerini oynayan oyuncuların makyajları bağlamında Atatürk'e "benzetilmiş/benzetilememiş" tartışmaları, makyaj sanatını gündemde tutmuş, makyaja ilgiyi artırmış ve makyaj konusunda farkındalık oluşturmuştur. Bu bağlamda dizi ve filmlerdeki Atatürk canlandırmalarıyla birlikte Türkiye'de makyaj olgusu daha önce hiç olmadığı kadar önemsenmiştir. Sinema ve televizyon dizilerinde ilk Atatürk canlandırmalarına baktığımızda özellikle Atatürk'e fiziksel olarak benzeyen oyunculara roller verildiği görülmüştür. Dünyanın çeşitli ülkelerinde gösterilmiş, Türkiye, Belçika ve Fransa ortak yapımı olan 1981 yapımı "Atatürk" belgeselinin yönetmen yardımcısı Zeynel Yeşilay (Kişisel görüşme 13 Temmuz 2019), belgeseldeki Atatürk rolü için, Atatürk'ün gençlik yıllarını Devlet Tiyatro Sanatçısı Cüneyt Çalışkur'a; son dönemini de Poul Andre Mussche'e sadece benzerlikleri için rol verdiklerini ifade ederek bu durumu ortaya koymuştur. 1987 yılında TRT'de yayınlanan "Ateşten Günler" dizisinde de bu durumu görmek mümkündür. Bu dizinin makyaj sanatçısı Yavuz Birsen (Kişisel görüşme 20 Temmuz 2019), dizideki Atatürk karakterini canlandıran Metin Belgin'nin sadece saçlarının boyatıldığını, kaşlarının yapıldığını ve lens takıldığı ama makyaj uygulaması adına detaylı bir çalışma yapılamadığını ifade eder. Dönemin en pahalı yapımlarından olan TRT’nin 1994 yapımı "Kurtuluş" dizisinde ve ardından yine TRT tarafından yapımı gerçekleştirilen "Cumhuriyet" sinema filminde ise Atatürk rolü için plastik makyaj yapılması gündeme gelmiş olmasına rağmen Atatürk rolünü canlandıran Rutkay Aziz’e plastik makyaj uygulaması yapılmamıștır. Teknik ve maddi olarak plastik makyaj yapma imkânlarına sahip olunmasına rağmen plastik makyajın tercih edilmemesinin nedenini, "Kurtuluş" ve "Cumhuriyet" filmlerinin makyaj şefi ve sanatçısı Cüneyt Ballı, şu sözlerle açıklamaktadır: 
“Kurtuluş ve Cumhuriyet filmlerindeki Atatürk karakterini canlandıran Rutkay Aziz’e hiçbir plastik makyajı uygulanmadı. Oyuncuya sadece saç ve bıyık anlamında ufak tefek șeyler yapıldı. Yönetmenimiz Ziya Özkan'ın o zaman bununla ilgili bir görüşmede de söylediği gibi, Atatürk karakteri yaratılırken ya da tasarlanırken bizim kesinlikle birebir Atatürk yaratmak gibi bir düşüncemiz yoktu o dönem. Sebep şuydu, karşımızda Atatürk'ün kendisi bile çıkıp gelse ve oynatsak inanın 100 kişiden 90 tanesi bu Atatürk'e benzemiyor diyecek ve yadırgayacak olmasıydı. Çünkü o bizim kalbimizde, gönlümüzde ve ruhumuzda yarattığımız bir kişilik. Dolayısıyla bunu yaratırken sadece şunu dedik: Fiziksel benzerliklerden ziyade ana noktaları baz alalım. İște nedir o? Göz rengi lens taktık, iște filmde dönemine göre bıyığını değiștirdik. Bir de saç rengini değiştirdik. Onun dışında birtakım gölgeler kullandık ama hiçbir plastik obje kullanmadık. Çünkü plastik makyajla işi zorlaştırmayalım, aksine oyuncuya yer açalım, oyuncu oyunuyla oyunu götürsün, biz ana noktaları benzetelim istedik. Bizde daha çok kişiliği ön plana çıkaracak bir karakter yaratım duygusu vardı orada. " (Kişisel görüşme 25 Temmuz 2019).
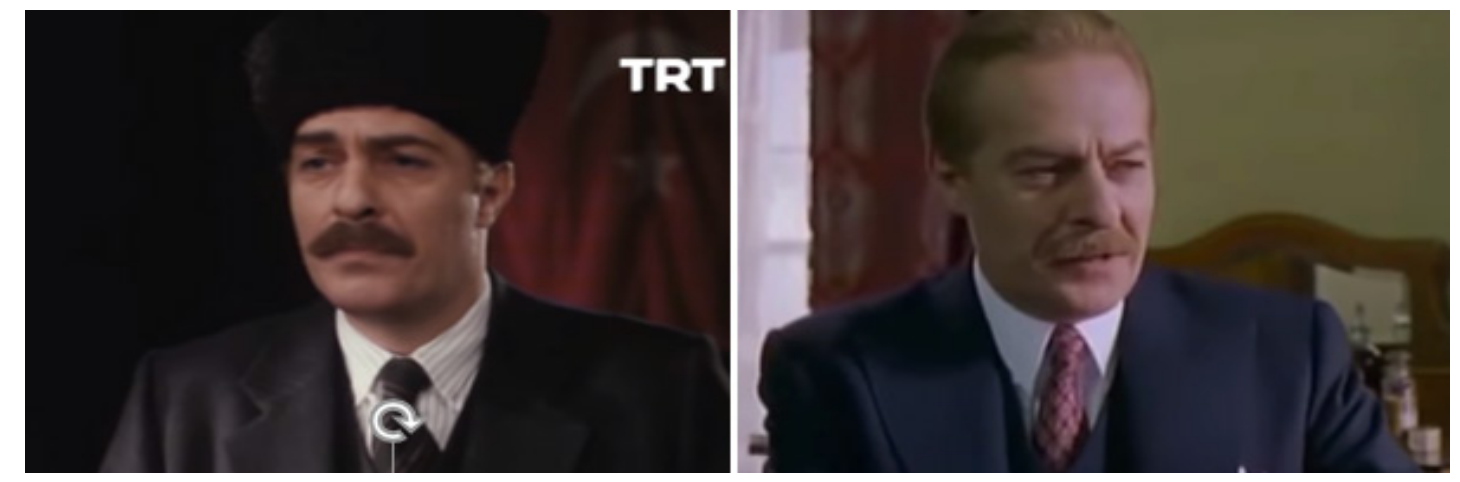

Şekil 11: Oyuncu Rutkay Aziz'in TRT'nin "Kurtuluş" (1994) dizisi (sol) ve "Cumhuriyet" (1998) filmindeki (sağ) Atatürk canlandırması. Makyaj Șefi: Cüneyt Ballı.

Cüneyt Ballı (Kişisel görüşme 25 Temmuz 2019) Atatürk makyajının haricinde TRT’nin hem "Kurtuluş" dizisi hem de "Cumhuriyet" filminde farklı plastik makyaj uygulamalarının da kullanıldığını belirtir ama çok yoğun bir kadro ve çok hızlı bir çekim ortamından dolayı bu yapımlarda plastik makyaj uygulamalarını karakter değişimi anlamında kişilerde göremezsiniz demektedir: "Savaş sahnelerinde, yaralanmalarda, birtakım benzer sahnelerde plastik makyaj kullanıldı. Savaş sahnelerinin gerçekçi olması anlamında Türkiye Sakatlar Konfederasyonu'ndan uzun sakatlıkları olan birtakım kişiler oyuncu olarak çağrıldı. Onların kol ve bacak uzuvlarında plastik makyaj yöntemleriyle savaşta anında kopma ve benzer sahneler yapıldı ve bu sahneler "Kurtuluş" ve "Cumhuriyet" filminde kullanıldı. Ama sonrasında birtakım sahneler çok fazla kanlı olduğu için bir kısmı sonradan kesildi, çıkarıldı." Yavuz Birsen (Kişisel görüşme 20 Temmuz 2019), bu yapımlardaki plastik makyajların aslında çok basit yüzeysel uygulamalar olduğunu detaylı bir plastik makyajın kullanılmadığını belirtir ama Türk sineması için bu uygulamaların bir geçiş olduğunu özellikle ifade eder. Bu geçişi sonraki yıllarda reklam, dizi ve sinema filmlerinde gerçekleştirilen Atatürk canlandırmalarındaki başarılı plastik makyaj uygulamalarıyla görmek mümkündür ama Türkiye'de plastik makyaj tıpkı kozmetik makyajda olduğu gibi zamanla gelişen bir olgu olarak karşımıza çıkmıştır ve özellikle 2000 sonrası dijital dönem Türk sinemasında çağdaşlarıyla yarışabilecek başarılı işler ortaya konulmuştur ama 2000 öncesi yerli film ve dizilerde plastik makyaj uygulamaları çok sınırlı sayıda kalmıştır. Çünkü plastik makyaj filmlerin öncelikle bütçesiyle alakalı bir durumdur. Ballı'nın "kullandığımız malzeme tamamen yurtdışı odaklı ya Amerika ya da Almanya'dan geliyor. Dolayısıyla inanılmaz paralarla geliyor malzeme. Türkiye'de maalesef kimse bu işin mali dökümüne katlanmak istemedi. Hiçbir sinema bütçesini bunun üzerine kurmadı. Projeler geliyordu mali ve maddi sebepten dolayı vazgeçiliyordu" 
(Kişisel görüşme 25 Temmuz 2019) sözleri bu durumu ortaya çıkarmaktadır. Benzer bir açılamayı plastik makyaj konusunda önde gelen kişilerden biri olan Derya Ergün (2011) şu sözlerle açıklar: "Bu iş hep bütçelere takılıyor. Çünkü malzemeleri pahalı. Bir de biz, aceleci milletiz. Bekleyemiyoruz. Dışarıdaki adam, şu malzemeyi yaparken 1 ay süre veriyor. Çünkü bunun kalıbı var, protezi var... Bizde 'Hemen bir hafta sonra gelsin' diyorlar. Mümkün değil, bunun bir mutfağı var, hazırlanması lazım. İsim vermek istemiyorum, beni biri arıyor 'Hamile göbeği lazım, yapar mısın?'... Hamile göbeği denilen şey 45 günde çıkıyor." Plastik makyajın bütçe olarak yerli filmleri etkilemiş olsa da Türk sinemasında makyaj teknolojisinin gelişmesi ve bu alanda uzman kişilerinin yetişmesi özellikle 90’lı yıllar sonrası yerli filmlerde makyajın karakter ve tip yaratımında en belirleyici araçlardan biri olmasına neden olmuştur.

\section{Sonuç}

Türk sinemasında makyaj sanatının ayrı bir uzmanlık gerektiren meslek alanı olarak kabul görmesi çok uzun yıllar almıştır. Türk sinemasında tiyatro geleneğinin bir devamı olarak ilk öykülü filmlere geçtikten sonra oyuncuların kendisi ya da setteki kişiler tarafından amatör ve bilinçsizce yapılan makyaj uygulamaları, daha çok makyaja ilgi duyan çok sınırlı sayıdaki kişiler tarafından kişisel gayretler ve deneyimlerle ssürdürülmüştür. Türk sinemasında makyaj 90’lı yıllara kadar yerli film jeneriklerinin çoğunda yer almamış ve gerçek anlamda önemsenmemiştir. Bu durumun başlıca temel nedenleri ise yerli film yapımında ucuzculuk anlayışı ile hareket eden dönemin yapımcılarının yeni maliyet kalemleri oluşturmak istememesi, Yeşilçam sinemasında yaşanan maddi imkânsızlıklar, uzman ve eğitimli kişilerin azlığı, malzeme sıkıntısı ve tiyatronun olumsuz etkileridir.

Yeşilçam sinemasında makyaj öncelikle "güzel görünüş" amaçlı kozmetik uygulamalarla başlamıș, daha sonra türlerin değișimiyle farklılaşmıştır. Takma sakal, bıyık ve kirpikler, briyantinli saçlar ve saçlara sürülen beyaz tozlarla yapılan yaşlandırmalarla başlayan ilk makyaj uygulamaları daha sonra polisiye, aksiyon, tarihi kostüme avantür yerli filmlerle birlikte daha çok çeșitli amatör boyalarla yara ve kanlı uygulamalar şeklinde devam etmiştir. Türk sinema sektörünün ekonomik ve teknolojik alt yapısının zamanla gelişmesiyle ve makyajları uygulayan kişilerin deneyimleri ve ustalıkları arttıkça yerli filmlerdeki makyaj uygulamaları ilk yıllara göre bir gelişme göstermiştir ama asıl büyük gelişme televizyonun gelişiyle olmuştur. Özellikle TRT'nin yapmış olduğu yatırımlarla alanında eğitimli makyaj sanatçıları yetişmiş, bu yetişen kişiler de makyaj konusunda uzman profesyonel bir jenerasyonun oluşmasına katkı sunmuştur. Mesleği profesyonel bilgi ve birikimleriyle yapan bu kişilerin hem TRT'nin dizi ve programlarında hem de sonradan açılan özel kanalların programlarında yapmış oldukları başarılı ve gerçekçi makyaj uygulamaları makyaj mesleğini Türkiye'de popüler hale getirmiş ve yerli sinemanın makyaj sanatına olan bakış açısını değiștirmiştir. Böylelikle de makyajın bir meslek olarak sinemada kabul görmesini sağlamıștır. Bu bağlamda da çoğu alaylı olan az sayıdaki sinemadaki makyaj sanatçılarının yerine karakter ve tip oluşturabilen eğitimli yeni kuşak makyajcılar sinema alanına girmiş ve bu sanatçılar çağdaşları ile yarışabilecek düzeyde kaliteli işler ortaya koymuşlardır.

\section{Notlar}

1 Söz konusu bu durum sonraki yerli film festivallerinde de yıllarca devam etmiştir. Makyaj başlığı altında ödüller ancak 2000'li yıllarda verilmeye başlanmıştır. Bu alanda Türkiye'de ilk ödül "41. Antalya Film Festivali”nde (3 Ekim 2004) “Makyaj ve Saç" başlığı altında "Yazı Tura" filminin Makyajcısı Sevinç Uçar’a ilk ödül verilmiştir. Daha sonra 42. Antalya Film Festivali'nde (2005), "0 Şimdi Mahkûm” filmiyle Fatma Kardeş Şengül ve Ümit Talip Bulut'a; 43. Antalya Film Festivali'nde 
(2006), “Takva” filmiyle Nimet İnkaya'ya; 44. Antalya Film Festivali'nde (2007) “Mutluluk' filmiyle ibrahim Karakız ve Fatma Kardeş'e; 45. Antalya Film Festivali'nde (2008) "Vicdan' filmiyle Vesey Üsten”e "En iyi Makyaj ve Saç" başıı̆ı altında ödüller verilmiş̧tir. Ama sonraki senelerde bu ödül kaldırılmıştır.

\section{Kaynakça}

Aktaş, Y. (2014). Türk Sinemasında Makyaj. B. Evren içinde, Türk Sinemasında Makyaj (s. 56-96). İstanbul: Türvak.

Aytuğ, M. S. (2010). Profesyonel Makyaj. İstanbul, Türkiye: Mitos Boyut Yayınları.

Aytuğ, S. (2014). Dünya Sinemasında Makyaj. B. Evren (Der.), Türk Sinemasında Makyaj. İstanbul: Türvak.

David Bordwell, K. T. (2012). Film Sanatı. Ankara: Deki.

Evren, B. (2014). Bir Makyaj Ustası: Cemal Gonca. B. Evren (Der.), Türk Sinemasında Makyaj (s. 106-117). İstanbul, Türkiye: Türvak.

Evren, B. (2014). Plastik Makyaj Görsel Efekt ve Muppette’ta Öncü Atölye: Bİ'CAN. B. Evren (Der.), Türk Sinemasında Makyaj (s. 136-141). İstanbul: Türvak.

Evren, B. (2014). Türk Sinemasında Duayen Yüz Kostümcüsü. B. Evren (Der.), Türk Sinemasında Makyaj (s. 118-131). İstanbul, Türkiye: Türvak.

Evren, B. (2014). Türk Sinemasının İlk Profesyonel Makyajcısı: Zeki Alpan. B. Evren (Der.), Türk Sinemasında Makyaj (s. 96-105). İstanbul: Türvak.

Evren, B. (2017, Ekim 26). Türk Sinemasında Makyaj ve Aksesuarların 100 yıllık Yolculuğu (Burçak Evren) [Video]. Erişim Adresi: https://www.youtube.com/ watch?v=9oltIB4Vqi0

Kabadayı, L. (2014). Film Eleştirisi: Kuramsal Çerçeve ve Sinemamızdan Örnek Çözümlemeler. İstanbul: Ayrintı.

Mascelli, J. V. (2007). Sinemanın 5 temel öğesi. Ankara: İmge Kitabevi.

Akad, Ö. L. (2004). Işıkla Karanlık Arasında. İstanbul: İletişim

Özön, N. (1985). Sinema Uygulayımı Sanatı Tarihi. İstanbul, Türkiye: Hil Yayın.

Ryan, M., \& Lenos, M. (2014). Film Çözümlemesine Giriş. Ankara: De Kİ.

Ün, M. (2009). Memnuh Ün Filmlerini Anlatıyor. İstanbul, Türkiye: Kabalcı.

Zengin, F. (2017). Türk Sinemasında Dijital Dönüşüm. İstanbul: Kalkedon.

Internet Kaynakları

Aytuğ, M. S. (2012, Aralık 22) Başlangıcından Günümüze Türk Sinemasında Makyaj

[Video]. Erişim Adresi: https://www.youtube.com/watch?v=IDJsZUKfupM

Büyükturan, N. (2016, Mart). Yıldız Olmak, Yıldız Kalmak. Erişim: Temmuz 7, 2019, http:// aksamsanat.com/bdm/ropdoc/hulyajocyigit-mart2016.pdf adresinden alındı

Doğancı, G. (2014, Ağustos 31). Özal babacan Çiller titiz Demirel rahat. Yenişafak. Erişim:Temmuz 12, 2019, https://www.yenisafak.com/yenisafakpazar/ozalbabacan-ciller-titiz-demirel-rahat-681082 adresinden alındı

Ergün, D. (2011, Haziran 18). Aman Allah'ım bu ben miyim? Posta. Erişim:Ocak 4, 2019 Posta: https://www.posta.com.tr/aman-allahim-bu-ben-miyim-76366 adresinden alındı 
İnanç, Ç. (2014, Aralık 14). 'Jet rejisör' Çetin İnanç, yönettiği filmi 31 yıl sonra ilk kez izledi. T24. Erișim: Ocak 3, 2019, https://t24.com.tr/haber/jet-rejisor-cetin-inancyonettigi-filmi-31-yil-sonra-ilk-kez-izledi,280361 adresinden alındı

Kara, M. (2013, Mayıs 14). Türk Sinemasının Darbeyle Imtihanı: Sinema ve 12 Eylül. Erişim: Temmuz 8, 2019, Tersninja.com: http://www.tersninja.com/turk-sinemasinindarbeyle-imtihani-sinema-ve-12-eylul-mesut-kara/ adresinden alındı

Muvahhit, B. (1973). Bedia Muvahhit’le Konuşma. Erişim: Nisan 19,2019. TSA: https:// www.tsa.org.tr/haber/roportaj/roportajgoster/1078/bedia-muvahhit-lekonusma/ adresinden alındı

Sinematürk. (2019). Kadir Inanır. Erişim: Mayıs 4, 2019. Sinematürk: http://www. sinematurk.com/kisi/1600-kadir-inanir/ adresinden alındı

Sinematürk. (2019). Müfit Kiper. Erişim: Nisan 13, 2019. Sinematürk: http://www. sinematurk.com/kisi/1835-mufit-kiper/ adresinden alındı

TDK. (2019, Nisan 10). Güncel Türkçe Sözlük. Erişim: Temmuz 4, 2019 tarihinde sozluk. gov.tr: http://sozluk.gov.tr/ adresinden alındı

TDK. (2019, Temmuz 16). Türk Dil Kurumu Sözlükleri. Erişim:Temmuz 16, 2019 tarihinde Sozluk.gov.tr: http://sozluk.gov.tr/ adresinden alındı

Tolga, O. (2019, 8 Temmuz). Oya Tolga BRT Hayat Güzeldir Programında 2. Bölüm. [Video]. Erişim Adresi: Youtube: https://www.youtube.com/watch?v=xCUxJgNEWdI

Tolga, O. (2019, 8 Temmuz.). Oya Tolga BRT Hayat Güzeldir Programında 2. Bölüm. [Video]. Erişim Adresi: Youtube: https://www.youtube.com/watch?v=M8lKuthnPn8

Tuğsal, S. (2016, Temmuz 24). Televizyonda Plastik Makyajı İlk Ben Uyguladım. 24saat. Erişim: Ocak 3, 2019, http://www.24saatgazetesi.com/sema-tugsal-televizyondaplastik-makyaji-ilk-ben-uyguladim/adresinden alındı

Turknostalji. (2012, Eylül 8). Tarkan Kolsuz Kahraman'a Karşı. Erişim: Ağustos 25, 2018. turknostalji: http://www.turknostalji.com/tarkan-kolsuz-kahramana-karsi.html adresinden alındı

Turknostalji. (2017, Nisan 10). Zeki Alpan Yeşilçam'ın Sihirli Elleri. Turknostalji. Erişim: Ağustos 28, 2018, http://www.turknostalji.com/zeki-alpan-yesilcamin-sihirlielleri.html adresinden alındı

Sinematürk. (1953). Beklenen Şarkı Sinema Filmi. Erișim: Temmuz 1, 2019. Sinematürk: http://www.sinematurk.com/film/2113-beklenen-sarki/fotograflar/?sayfa=2 adresinden alındı

Ulusoy, Ö. (2018, Ağustos 28). Düşleri Mavi Sanatçı. Erişim: Ağustos 28, 2018, http://www. seninle.com.tr/yazarlar/ozge-ulusoy/2130-ozge-ulusoy.html adresinden alındı

Yerli Film Yapanlar Cemiyeti. (1946). Filmlerimiz. (A. K. Arşivi, Dü.) Erişim: Ağustos 26, 2018. Academia: https://www.academia.edu/10943556/Filmlerimiz_Yerli_Film_ Yapanlar_Cemiyeti_adresinden alındı 


\title{
From Photogenic Make-Up to Plastic Make-Up: Overview of Make-Up in Turkish Cinema before 2000s
}

\author{
Ferhat Zengin (Asst. Prof. Dr.)
}

\section{Extended Abstract}

One of the elements that increase visual effect of cinema is make-up. Make-up is the most important narrative tool to create stage atmosphere and cinematic reality feeling and make-up is especially needed to reflect personalities staged by actors in character and type creation. Therefore, from the birth of motion images, make-up has been accepted as an occupation in film industry, applications of make-up artists have been cared and rewarded. In Turkish cinema that experienced significant issues in terms of becoming a sector has been overlooked for years and struggled to exist as an occupation for long years. In this study, historical development and transformation of make-up art in Turkish cinema is considered and position of make-up art in pre-2000s Turkish local cinema is investigated. It has taken many years for the art of makeup to be recognised as a profession that requires separate expertise in Turkish cinema. As a continuation of the theatrical tradition in Turkish cinema, after the first story films, the performances of the amateur and unconscious makeup performed by the actors themselves or by the people in the set were carried on by personal efforts and experiences by a very limited number of people interested in makeup, however, it was not included in most of the native film credits and was really ignored. The main reasons for this situation are the fact that the producers of the period who do not want to create new cost items, financial difficulties experienced in Yeşilçam cinema, the lack of material and lack of expert and educated people, the shortage of materials, and the negative effects of the theatre.

Zeki Alpan and Cemal Gonca differentiated from the others with successful makeup applications in the local films from the 1950s to 70s. These people who developed themselves in makeup have been included in the credits of the films as makeup artists of many local films. In the late 1970 s and early 80 s, educated and professional people who would make significant contributions to the art of makeup in Turkish cinema became involved in the domestic film industry. The most important of these individuals are Yavuz Birsen and Oya Tolga, who were educated abroad. Birsen and Tolga are the first makeup artists in the Turkish cinema to perform the makeup art professionally. Yavuz Birsen, known as Corci in the sector, realised essential works in Turkish cinema about plastic makeup applications. According to Burçak Evren (2014, s. 100-118) who stated that together with Corci, makeup character emerged beyond the ugliness and beautification of makeup in Turkish cinema, Corci is the one who brought makeup to a contemporary position in Turkish cinema.

In Yeşilçam cinema, makeup first started with cosmetic applications for "beautiful appearance" and then differentiated with the change of genres. The first makeup applications, which started with artificial beards, moustaches and eyelashes, hair with brilliantine and aging made with white powder applied to the hair, then continued in the form of wound and bloody applications with a wide variety of amateur dyes, along with local films such as police, action, historical costume and adventure films. With the development of the economic and technological infrastructure of the Turkish cinema sector over time and the experience and mastery of the people applying the makeup, the 
makeup applications in the local films have significantly improved compared to the initial years, but the significant development has been experienced with the advent of television.

Especially with the investments made by TRT, trained makeup artists have been trained, and these people have contributed to the formation of a professional generation of experts in makeup profession. The successful and realistic makeup applications made by these people who do the profession with their professional knowledge and experience both in TRT's series and programs as well as in the programs of the private channels that were founded later made the makeup profession popular in Turkey and changed the perspective of the local cinema on the art of makeup. In this context, instead of the few make-up artists, most of whom are self-taught in the cinema, the new generation of makeup artists who are trained in the field of television have entered the field of cinema, and these artists have demonstrated successful makeup practices that can compete with their contemporaries.

With the foundation of private channels since the late 1980s, competition between television channels has increased. This competition in a short time brought about the diversity of genres seen in television programs. With the production of many contents such as television films, historical series, comedy programs, magazine programs, the art of makeup has gained a prominent position and plastic makeup has become popular beyond cosmetic makeup, which stands out in character formation. Another development that popularised the phenomenon of makeup in Turkey is the portrayal of Mustafa Kemal Atatürk, the founder of the Republic of Turkey, in television series and films. The discussions of "resembles/not resembles" Atatürk in the context of the makeup of the actors who played the roles of Atatürk in the series and films kept the art of makeup always on the agenda, increased interest in makeup, and raised awareness about it. In this sense, with the portrayals of Atatürk in the series and films, the phenomenon of makeup in Turkey has become more important than ever before.

This study applied in-depth interviews, literature and archive review and various make-up applications are presented with purpose-oriented local movies. Thus, based on obtained data, states of make-up in Turkish cinema before 2000s has been reflected. According to this study, after transition to first story films as a continuation of theatre tradition, make-up applications for "beautiful look" applied unconsciously by directors, actors or set personnel in Turkish cinema is later sustained by personal efforts and experience of limited number of individuals interested in make-up. Raising expert and professional artists who can apply plastic make-up for character and type creation in Turkish cinema started with television.

Keywords: Turkish Cinema, Make-up, Cosmetic Make-up, Plastic Make-up. 
